\title{
The Role of the Western Arabian Sea Upwelling in Indian Monsoon Rainfall Variability
}

\author{
TAKESHI IZUMO
}

Frontier Research Center for Global Change, Japan Agency for Marine-Earth Science and Technology, Yokohama, Japan, and Laboratoire d'Océanographie et du Climat: Expérimentation et Approches Numériques, IPSL, Paris, France

\section{Clément de Boyer Montégut, Jing-Jia Luo, and Swadhin K. Behera}

Frontier Research Center for Global Change, Japan Agency for Marine-Earth Science and Technology, Yokohama, Japan

\author{
SÉBASTIEN MASSON
}

Laboratoire d'Océanographie et du Climat: Expérimentation et Approches Numériques, IPSL, Paris, France

\section{Toshio Yamagata}

\begin{abstract}
Department of Earth and Planetary Science, The University of Tokyo, Tokyo, and Frontier Research Center for Global Change,
\end{abstract} Japan Agency for Marine-Earth Science and Technology, Yokohama, Japan

(Manuscript received 24 July 2007, in final form 23 April 2008)

\begin{abstract}
The Indian summer monsoon rainfall has complex, regionally heterogeneous, interannual variations with huge socioeconomic impacts, but the underlying mechanisms remain uncertain. The upwelling along the Somalia and Oman coasts starts in late spring, peaks during the summer monsoon, and strongly cools the sea surface temperature (SST) in the western Arabian Sea. They restrict the westward extent of the Indian Ocean warm pool, which is the main moisture source for the monsoon rainfall. Thus, variations of the Somalia-Oman upwelling can have significant impacts on the moisture transport toward India. Here the authors use both observations and an advanced coupled atmosphere-ocean general circulation model to show that a decrease in upwelling strengthens monsoon rainfall along the west coast of India by increasing the SST along the Somalia-Oman coasts, and thus local evaporation and water vapor transport toward the Indian Western Ghats (mountains). Further observational analysis reveals that such decreases in upwelling are caused by anomalously weak southwesterly winds in late spring over the Arabian Sea that are due to warm SST/increased precipitation anomalies over the Seychelles-Chagos thermocline ridge of the southwestern Indian Ocean (and vice versa for years with strong upwelling/weak west Indian summer monsoon rainfall). The latter SST/precipitation anomalies are often related to El Niño conditions and the strength of the Indonesian-Australian monsoon during the previous winter. This sheds new light on the ability to forecast the poorly predicted Indian monsoon rainfall on a regional scale, helped by a proper ocean observing/forecasting system in the western tropical Indian Ocean.
\end{abstract}

\section{Introduction}

The Indian summer monsoon rainfall affects densely populated regions. Slight changes in its strength and spatial distribution have massive societal impacts. Un-

Corresponding author address: Takeshi Izumo, Climate Variations Research Program, FRCGC, JAMSTEC, 3173-25 Showamachi, Kanazawa-ku, Yokohama, Kanagawa 236-0001, Japan.

E-mail: izumo@jamstec.go.jp derstanding what controls its variability is thus important. By involving ocean-atmosphere-land coupling processes, the monsoon is in principle influenced by large-scale oceanic, atmospheric, and/or land conditions and by interannual phenomena such as the El Niño-Southern Oscillation (ENSO) (Walker 1924) and the Indian Ocean Dipole (IOD) (Reverdin et al. 1986; Saji et al. 1999; Webster et al. 1999; Murtugudde and Busalacchi 1999; Murtugudde et al. 2000). Intraseasonal oscillations, partly related to the Madden-Julian 

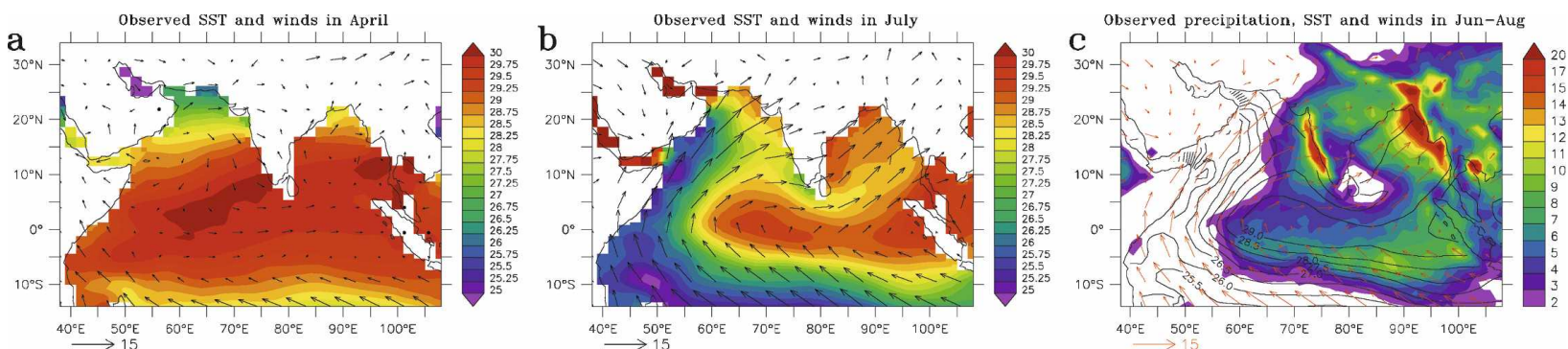

FIG. 1. Observations evidencing the cooling and reduction of the warm pool extent by Somalia-Oman upwelling in (b) July compared to (a) April, and (c) the June-August monsoon. Climatological SST (NOAA OI SST V2; 1982-2006) in (a) April, (b) July (color, ${ }^{\circ} \mathrm{C}$ ), and (c) June-August (black contours, ${ }^{\circ} \mathrm{C}$ ). In (c) TRMM precipitation (color, mm day ${ }^{-1}$ ) and SST are regridded, respectively, on the $1.125^{\circ} \times 1.125^{\circ}$ atmospheric and $2^{\circ} \times 0.5^{\circ}-2^{\circ}$ oceanic grids of the model for accurate comparison; the 10-m winds (Quikscat over sea; NCEP over land) are added (arrows, $\mathrm{m} \mathrm{s}^{-1}$ ). In (c) the same scale as in Fig. 2a is used for validation of the model.

oscillation (Madden and Julian 1972), also influence the monsoon seasonal average (Yasunari 1979; Lawrence and Webster 2001; Annamalai and Sperber 2005). Numerous existing studies, aimed at improving monsoon ${ }^{1}$ predictability, have highlighted various relationships between Indian monsoon rainfall interannual variations and factors such as Indo-Pacific SST (Parthasarathy et al. 1988; Terray and Dominiak 2005), the premonsoon $500-\mathrm{hPa}$ ridge location along $75^{\circ} \mathrm{E}$ over India (Mooley et al. 1986), sea level pressure (Parthasarathy et al. 1992), tropospheric winds (Parthasarathy et al. 1991a), Indian land surface temperature (Mooley and Paolino 1988), and snow cover over the Himalayas and Eurasia [Hahn and Shukla 1976 (see Shukla 1987; Pant and Rupa Kumar 1997; Webster et al. 1998 for review)].

However, issues such as the tendency to use overlarge regions to define monsoon indices that average out important spatial variations (Pant and Rupa Kumar 1997), important uncertainties in SST products (Shukla 1987; Rao and Goswami 1988; Terray 1995; Vecchi and Harrison 2004), interactions with the intraseasonal active and break monsoon phases, and interdecadal changes in the ambiguous relationships between monsoon and ENSO (Parthasarathy et al. 1991b; Pant and Rupa Kumar 1997; Krishna Kumar et al. 1999, 2006; Annamalai and Liu 2005) or IOD (Ashok et al. 2001) blur the picture, leading to conflicting conclusions. Hence, there is no clear consensus on the mechanisms of monsoon interannual variability, and the influence of the Indian Ocean on monsoon variability remains an open question (Slingo et al. 2004; Annamalai and Murtugudde 2004). This limited understanding has been a big barrier to predicting the monsoon. Predictions are uncertain and often fail (Gadgil et al. 2005).

\footnotetext{
${ }^{1}$ In the present article, to avoid confusion when using the degenerated word "monsoon," we discuss monsoon rainfall.
}

The Indian Ocean warm pool (the warmest in the world in April-May, Joseph 1990) is the main moisture source for the monsoon rainfall (Ninomiya and Kobayashi 1999). However, the extent of the warm pool (defined as SST $>28^{\circ} \mathrm{C}$ ), which maximizes in April, is reduced in summer by almost half, mainly by the Somalia-Oman upwelling and partly by latent heat flux increase in the Arabian Sea (Fig. 1; see also de Boyer Montégut et al. 2007; Murtugudde et al. 2008). Because of a shallow mixed layer $(15-30 \mathrm{~m})$ in spring and summer, SST in the western Arabian Sea coastal zone is very sensitive to upwelling variations (de Boyer Montégut et al. 2007; Fischer et al. 2002), like the cold tongue in the equatorial Pacific. The upwelling appears in late spring and peaks during summer, caused by the strong low-level southwesterly Findlater (1969) jet and consequent southeastward offshore Ekman ocean transport. They are fed by cold thermocline waters, rich in nutrients (Brock and McClain 1992; Wiggert et al. 2002), brought by the subsurface Somalia western boundary northeastward current (Schott and McCreary 2001; Schott et al. 2002). These upwellings strongly cool the SST in the western Arabian Sea (Fig. 1; de Boyer Montégut et al. 2007). A slight change in their strength can thus have great impacts on the SST and extent of the warm pool, and hence on monsoon precipitation. Shukla (1975) showed, in a pioneering paper using a simple forced atmosphere model, the possible influence of western Arabian Sea SST on Indian monsoon precipitation. After the conflicting modeling results of Washington et al. (1977), a more recent modeling study (Arpe et al. 1998) also highlighted the possible importance of northern Indian Ocean SST (versus Pacific SST) on Indian rainfall. In observations, Shukla (1987) discussed the relation between Arabian Sea SST and Indian monsoon rainfall variability and highlighted the lack of accurate past observations. During 19822001, summer SST over the western Arabian Sea is, 
indeed, significantly positively correlated to summer monsoon precipitation over the Indian Western Ghats (mountains) (Vecchi and Harrison 2004).

The following questions naturally arise: what happens to the Indian monsoon when the Somalia-Oman upwellings vary in their strength and influence on SST? Why and when do they really vary from year to year? Can their variations be related to previous spring, winter, and even fall conditions in the Indo-Pacific domain? The present study tries to answer these questions by combining both modeling and observational approaches.

Section 2 presents model experiments, observational data, and methods. In section 3, the hypothesis that year-to-year changes in upwelling influence Indian monsoon variability is tested through both model experiments and observational analysis. Section 4 will focus on understanding the origins of such upwelling changes. The results are discussed further in section 5, before final conclusions and perspectives are offered in section 6 .

\section{Model and data}

\section{a. The coupled model}

The global coupled ocean-atmosphere general circulation model (CGCM) used is the relatively high resolution Scale Interaction Experiment-Frontier Research Center for Global Change SINTEX-F) model (Luo et al. 2003; Masson et al. 2005; Luo et al. 2005b) developed at FRCGC under a European Union-Japan collaboration. The oceanic component is the Océan Parallélisé (OPA) ocean GCM (OGCM) version 8.2 (Madec et al. 1998 ), with a resolution of $2^{\circ}$ longitude, $0.5^{\circ}$ (near the equator) to $2^{\circ}$ latitude (ORCA2 grid), and $10 \mathrm{~m}$ vertically in the first $150 \mathrm{~m}$. The atmospheric component is the ECHAM4.6 (Roeckner et al. 1996) Atmosphere GCM (AGCM) with a high horizontal resolution of $1.125^{\circ} \times 1.125^{\circ}(\mathrm{T} 106$ spectral grid $)$ and 19 hybrid sigma-pressure levels in the vertical. The Ocean Atmosphere Sea Ice Soil (OASIS 2.4) coupler (Valcke et al. 2000 ) is used with improved coupling physics (Luo et al. 2005b), with 2-h coupling intervals.

A sensitivity experiment (SENS) has been done to assess how the Indian Ocean and monsoon respond to Somalia-Oman upwelling variations. In SENS, the spring increase and summer maximum of SomaliaOman upwelling are removed by imposing over the Indian Ocean the annual mean wind stress of the control experiment (CTL). At least a 70-yr time span was computed for each experiment so that mean values and seasonal cycles could be calculated over 50 years after discarding the first 20 years to account for spinup. In
SENS, the oceanic component of the CGCM is forced over the Indian Ocean by a constant wind stress (equal to the 50-yr mean of the CTL experiment) instead of the varying wind stress of the atmospheric component. All other fluxes are still calculated with varying winds of the atmospheric component. The ocean in SENS is hence dynamically decoupled from the atmosphere but still coupled thermodynamically. The Indian Ocean circulation becomes nearly steady, similar to the $50-\mathrm{yr}$ mean circulation of CTL. The spring increase and summer maximum of Somalia-Oman upwelling are hence removed.

\section{b. Observational data and analysis method}

The observational analysis uses mainly two precipitation products: a land-gauge-based product [19482006, Precipitation Reconstruction over Land (PREC/ L) from the NOAA National Centers for Environmental Prediction/Climate Prediction Center (NOAA/ NCEP/CPC) (Chen et al. 2002), and the CPC Merged Analysis of Precipitation (CMAP), which merges in situ and satellite data (1979-2006) (Xie and Arkin 1996). The SST data used are the NOAA optimum interpolation (OI) SST version 2 (V2) in situ/satellite data product (Reynolds et al. 2002) for 1982-2006 and extended reconstructed SST (ERSST) V2 data (Smith and Reynolds 2004) for 1948-81 [data provided by NOAA/Office of Oceanic and Atmospheric Research/Earth System Research Laboratory (OAR/ESRL) Physical Sciences Division (PSD), Boulder, Colorado, from their Web site at http://www.cdc.noaa.gov]. Winds, latent heat flux, and specific humidity are obtained from the NCEP-National Center for Atmospheric Research (NCAR) reanalysis (1948-2006; Kalnay et al. 1996; Kistler et al. 2001). Finally, the more accurate Tropical Rainfall Measuring Mission (TRMM) sea-land precipitation and Quick Scatterometer (QuikSCAT) sea winds-available since 1998 and 1999, respectivelyare used to provide improved climatological estimations and to validate the coupled model.

Linear regression analyses are presented here for the 28-yr period 1979-2006 (satellite observations era, 1979 being the starting year of the CMAP precipitation merged product) with correlations (corr), regression slopes, and significance levels. These regressions give similar results to composites but with more statistical information. For clarity and easier comparison with the model experiments, all figures and discussions consider the case of anomalously strong monsoon precipitation along the Indian west coast. For cases of anomalously weak precipitation, the arguments can simply be reversed. Significance levels are calculated using the Stu- 

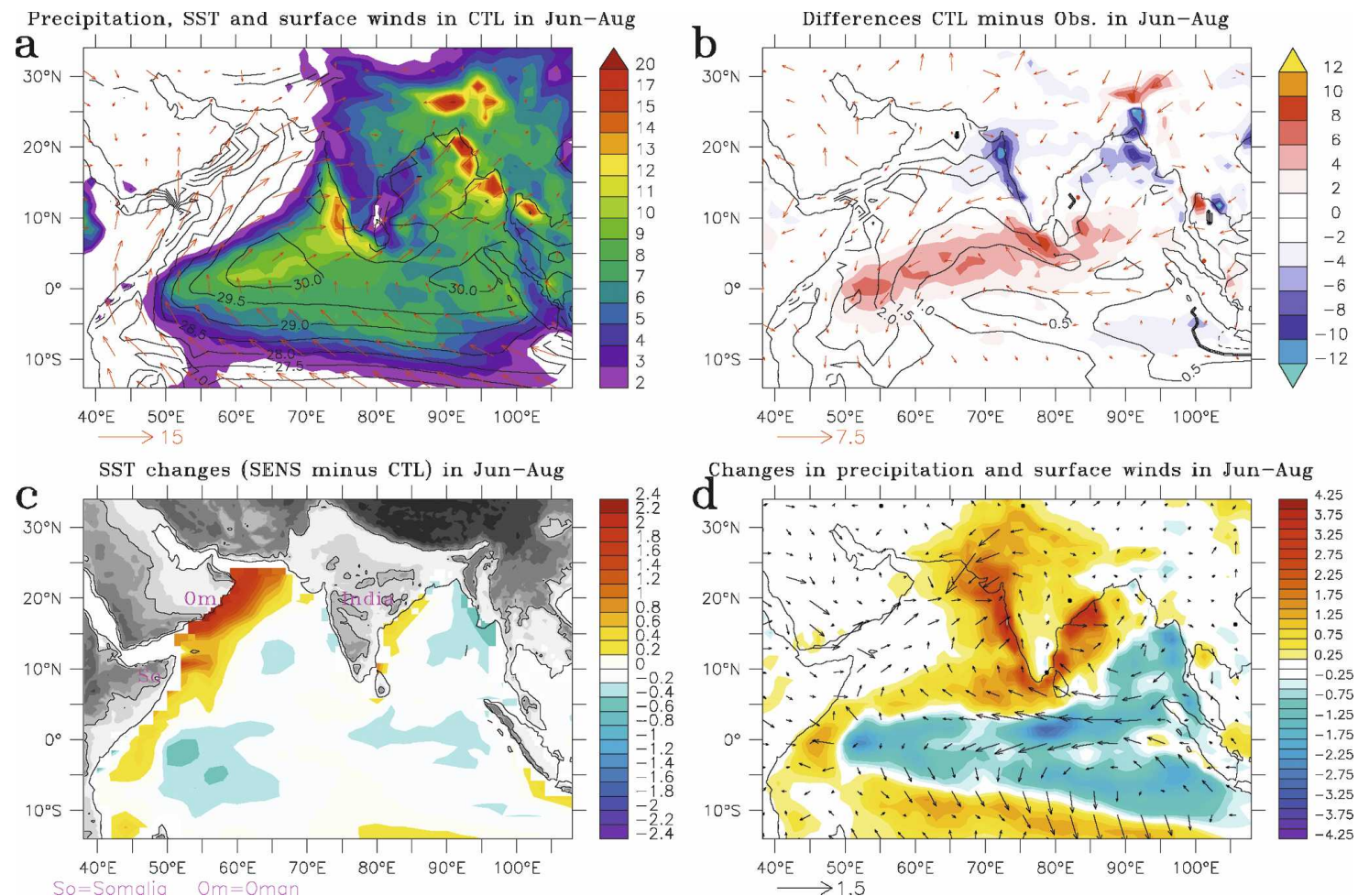

FIG. 2. Summer monsoon in (a) the CTL experiment, (b) differences with observations, and changes in (c) SST and (d) precipitation in the SENS experiment: in (a) precipitation (colors, $\mathrm{mm} \mathrm{day}^{-1}$ ), SST (black contours, ${ }^{\circ} \mathrm{C}$ ), and $10-\mathrm{m}$ winds (red arrows, $\mathrm{m} \mathrm{s}^{-1}$ ) in CTL. (b) Differences with observations (i.e., between Figs. 2a and 1c; note that wind scale has been doubled to better see the biases of the coupled model). Difference SENS - CTL in (c) SST (colors, $\left.{ }^{\circ} \mathrm{C}\right)$ and (d) precipitation (colors, $\mathrm{mm} \mathrm{day}^{-1}$ ) and 10-m winds (arrows). Land topography is added in (c): levels every $250 \mathrm{~m}$ between 0 and $1000 \mathrm{~m}$ and a black contour at $500 \mathrm{~m}$ highlights the Western Ghats (mountains) along the Indian west coast, with altitude between 500 and $1000 \mathrm{~m}$, and other mountain ranges that anchor precipitation (Xie et al. 2006).

dent's $t$ test. Computations using permute and scramble type tests have also been done and give similar results.

\section{The influence of upwelling SST on Indian monsoon rainfall}

\section{a. Model results}

\section{1) VALidation}

The SINTEX-F CGCM simulates rather well the summer monsoon, the large-scale cooling associated with the Somalia-Oman coastal upwelling, and the extent of the warm pool (Fig. 2a, with regards to Fig. 1c). The model also simulates fairly realistically the monsoon rainfall and its spatial distribution associated with topography (Xie et al. 2006), which is particularly difficult to simulate in CGCMs (Meehl et al. 2005). However, the monsoon winds are too weak in the Arabian Sea, as is precipitation along the Indian west coast, which is somewhat shifted to the south, leading to the differences between CTL and observations shown in
Fig. 2b. Note that SST in CTL is too warm compared to observations, notably in the west and central-north equatorial Indian Ocean, explaining the too strong precipitation over that area in CTL. This CGCM is used to study and predict the IOD (Luo et al. 2005a, 2007) and ENSO phenomena (Luo et al. 2005a, 2008), which have relatively realistic interannual variations in this model, and to study Indo-Pacific interactions (Behera et al. 2006). For details and further validations of the CGCM version used here, readers are referred to previous publications (Masson et al. 2005; Luo et al. 2005b; Yamagata et al. 2004).

\section{2) SST AND PRECIPITATION CHANGES}

We first analyze how the reduction of summer coastal upwelling in the SENS experiment affects SST and the monsoon. Coastal upwelling and offshore southeastward horizontal advection of upwelled water usually lead to SST cooling. The cooling rate in the coastal western Arabian Sea is about $4^{\circ} \mathrm{C}$ per month during June-August (JJA) (de Boyer Montégut et al. 

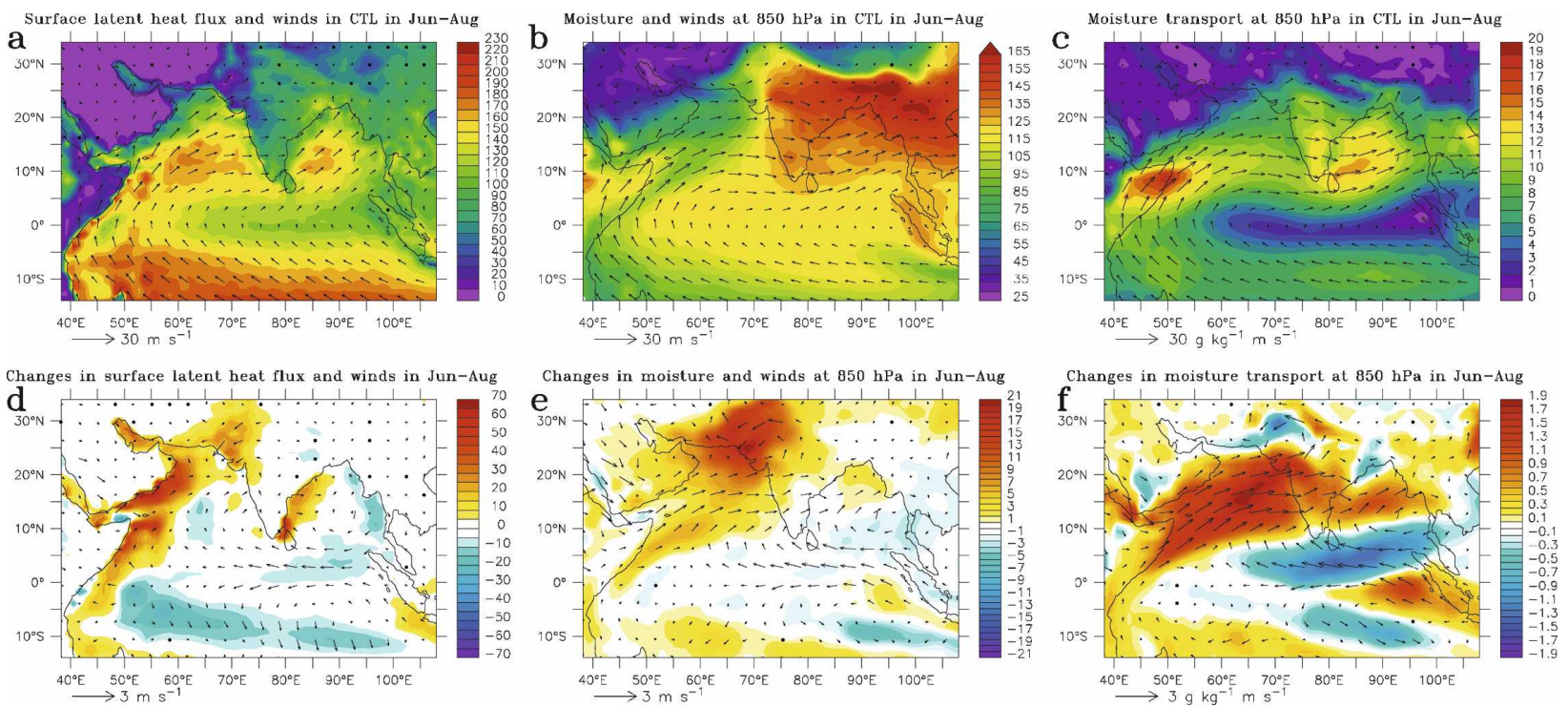

FIG. 3. Mechanism for the west Indian monsoon rainfall increase in SENS: (a), (d) Surface latent heat flux and 10-m winds (color, $\mathrm{W} \mathrm{m}{ }^{-2}$; arrows, $\mathrm{m} \mathrm{s}^{-1}$ ); (b), (e) specific humidity and winds (color, $\mathrm{g} \mathrm{kg}^{-1}$; arrows, $\mathrm{m} \mathrm{s}^{-1}$ ); and (c), (f) moisture transport (arrows with module in color, $\mathrm{g} \mathrm{kg}^{-1} \mathrm{~m} \mathrm{~s}^{-1}$ ) at $850 \mathrm{hPa}$ in June-August in (top) the CTL run and (bottom) for the difference SENS - CTL [with scales of about $10 \%$ of (top)]. Mean winds at $850 \mathrm{hPa}$ [arrows in (b)] show air masses trajectories at $850 \mathrm{hPa}$ are more zonal than at the surface [arrows in (a)] in the Arabian Sea. These arrows show that low-tropospheric air going over the Somalia-Oman upwelling feed moisture to the north and central west coast of India. Characteristic transport time is short, of the order of 2-3 days.

2007). Figures $2 \mathrm{c}$ and $2 \mathrm{~d}$ show the differences between the SENS and CTL experiments for SST, winds, and monsoon rainfall in summer. The upwelling reduction between May and September leads to a strong warming of up to $2^{\circ} \mathrm{C}$ along the Somalia-Oman coasts in summer (see Fig. 2c and the mixed layer heat budget shown in appendix A, Fig. A1). The warming tendency is partly damped by evaporation and associated latent heat loss: these are greater in SENS from June to November when the SST in SENS becomes warmer than that in CTL (Figs. 2c and A1).

The changes in summer precipitation in SENS are remarkable (Fig. 2d). Some of the precipitation increases-such as that in the western Bay of Bengal, where high summer SST $\left(29^{\circ}-30^{\circ} \mathrm{C}\right)$ makes convection very sensitive to small SST changes-are caused by local SST warming associated with coastal downwelling anomalies. A similar but opposite effect occurs in the eastern Bay of Bengal (see Figs. 2c and 2d). The most important change, however, is a large increase in monsoon rainfall strength of up to $4.3 \mathrm{~mm}$ day $^{-1}$ (about $30 \%$ of CTL) and its northward expansion along the Indian west coast. Interestingly, neither the small southwesterly wind anomalies over the Arabian Sea converging toward the west Indian precipitation zone $\left(\sim 0.5 \mathrm{~m} \mathrm{~s}^{-1}\right.$, about $5 \%$ of CTL) nor the local SST changes along the Indian west coast (which are in fact negative, and caused by the precipitation increases) can explain this strong increase in monsoon precipitation. Note that the wind anomalies (small, less than $10 \%$ of CTL values) are related to the precipitation anomalies and not directly with the SST anomalies out of the equatorial band. This is consistent with the fact that land-sea surface temperature contrast is only the basic driver and trigger of the monsoon and that the monsoon's main energetic source is latent heating associated with moisture convergence and cumulus convection (Holton 1992).

\section{3) Moisture Changes}

To understand such a strengthening of summer monsoon rainfall in SENS, we analyzed the moisture budget. In CTL, June-August mean latent heat flux (Fig. 3a) is primarily controlled by wind speed over the warm pool (where SST is nearly uniform and warm) and by SST in the Somalia-Oman upwelling region (where winds are strong). In SENS, latent heat flux changes in the north Indian Ocean (Fig. 3d) are essentially caused by SST changes (Fig. 2c) and not by the weak changes in wind speed. Evaporation increases (decreases) in warmer (colder) regions, particularly in the upwelling region along the Somalia-Oman coasts. Here the latent heat flux/SST ratio increase is about $30 \mathrm{~W} \mathrm{~m}^{-2}{ }^{\circ} \mathrm{C}^{-1}$. Because of the enhanced evaporation, the specific humidity anomalies of the lower-tropospheric air masses flowing over the upwelling region gradually increase as 

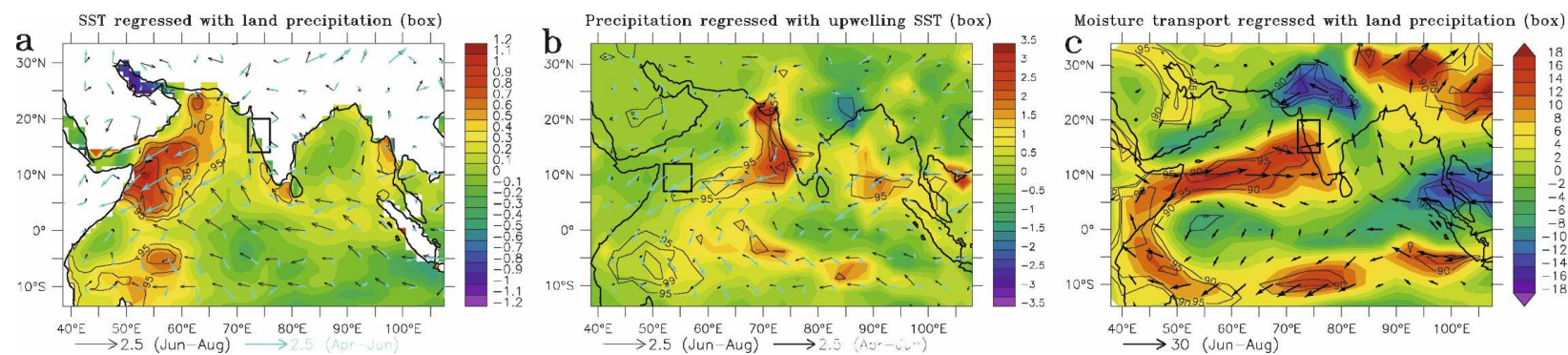

FIG. 4. Influence of upwelling SST in summer on the west Indian monsoon rainfall confirmed by a regression analysis using observations during 1979-2006: (a) SST and 10-m winds regressed with land precipitation (PREC/L) on the central-northwest coast (box: $14^{\circ}-20^{\circ} \mathrm{N}, 72^{\circ}-76^{\circ} \mathrm{E}$; regression slopes units: ${ }^{\circ} \mathrm{C}$ and $\mathrm{m} \mathrm{s}^{-1}$ per $5 \mathrm{~mm}$ day ${ }^{-1}$ ); (b) CMAP sea-land precipitation and $10-\mathrm{m}$ winds regressed with SST in the Somalia-Oman upwelling region (box: $7^{\circ}-12^{\circ} \mathrm{N}, 52^{\circ}-57^{\circ} \mathrm{E}$; units: $\mathrm{mm}^{-1 a y}{ }^{-1}$ and $\mathrm{m} \mathrm{s}^{-1}$ per ${ }^{\circ} \mathrm{C}$ ); (c) As in (a) but for specific humidity transport at $850 \mathrm{hPa}$ (unit: $\mathrm{g} \mathrm{kg}^{-1} \mathrm{~m} \mathrm{~s}^{-1}$ per $5 \mathrm{~mm}$ day ${ }^{-1}$ ). Linear regression slopes in June-August are in color/black arrows. Black contours in (a) and (b)/(c) show the $95 \% /(90 \%), 99 \% /(95 \%)$, and 99.9\%/(99\%) significance levels. Regressed winds in late spring (April-June) are added as blue arrows in (a) and (b) to evidence the weaker upwelling before a summer with strong west Indian monsoon rainfall. Box in (b) is taken as a sample, summer SST varying coherently over all of the western Arabian Sea upwelling region on interannual time scale. Note that a $5 \mathrm{~mm}$ day $^{-1}$ anomaly represents a relative anomaly of about $30 \%$ of the monsoon precipitation along the Indian west coast, the standard deviation for interannual variations being of about $10 \%-15 \%$.

the air moves toward India (Fig. 3e). Water vapor transport thus increases over the entire Arabian Sea toward the coastal Western Ghats of India (Fig. 3f; see Fig. 2c for topography), increasing precipitation there. These increases in evaporation, moisture transport, and precipitation consistently correspond to the same water transport anomaly of the order of $10^{4} \mathrm{~m}^{3} \mathrm{~s}^{-1}$ for each section (upwelling region, low-troposphere meridional section over the Arabian Sea, and Indian west coast region). Latent heat release associated with precipitation along the coast enhances low-level moisture convergence and thus wind convergence (Fig. 2d) through a (conditional instability of the second kind) CISK-like mechanism (Charney and Eliassen 1964).

\section{b. Observational analysis}

The modeling approach described above evidenced the influence of alongshore winds, coastal upwelling and associated SST variations along Somalia-Oman on Indian monsoon rainfall strength. The natural question, then, is whether such an influence can be found using the accurate observations available since 1979 (beginning of satellite era).

\section{1) Summer SST-PRECIPITATION REGRESSION ANALYSIS}

Figures $4 \mathrm{a}$ and $4 \mathrm{~b}$ show linear regressions between precipitation and SST in summer. The regression in Fig. 4a shows that enhanced precipitation on the central to north Indian west coast is usually associated in summer with warmer SST east of Somalia-Oman, and remarkably not with increased southwesterlies (vice versa for a year with a weak monsoon on Indian west coast). The correlation, associated with this linear regression, between SST in the upwelling region and land gauge precipitation on the central and north part of Indian west coast in summer is remarkably high during the 28 -yr period 1979-2006, with regards to the many climatic factors that can influence the monsoon (consistent with the Vecchi and Harrison 2004 study over the shorter 20 -yr period 1982-2001). The correlation peaks at 0.75 east of Somalia, thus explaining more than $50 \%$ of rainfall interannual variance. With sea-land CMAP precipitation, the correlation decreases to about 0.6. This decrease might be due to the lower accuracy of the CMAP data inferred partly from satellites (Xie et al. 2006). Precipitation interannual variations are relatively small, of the order of $10 \%-15 \%$ of the summer average, and hence sensitive to observational accuracy. Furthermore, regressions have been done using various spatial averages of PREC/L land precipitation and CMAP sea-land precipitation. These regressions confirm that upwelling SST is positively correlated mostly with rainfall over the central and northern part of the Indian west coast. Interestingly, this west Indian monsoon rainfall is not well correlated either with Niño-3.4 SST (corr: 0.14) or with IOD index (Saji et al. 1999, corr: 0.38) of the simultaneous June-August summer period over 1979-2006. June-August land precipitation on the Indian west coast is thus mostly influenced by SST variations in the Somalia-Oman upwelling region.

As shown by the reversed linear regression (Fig. 4b), warmer SST in the upwelling region is actually associated with enhanced precipitation over most of the eastern Arabian Sea and western India. Conversely, this warmer SST is associated with slightly decreased precipitation over northeast India, evidencing a west-east 
Indian rainfall dipole (see definition and discussion in section 5a). Note that west Indian monsoon rainfall participates largely in all Indian summer rainfall interannual variability: JJA land precipitation averaged over the central to northwest coast (box in Fig. 4a) and over a larger Indian domain $\left(5^{\circ}-25^{\circ} \mathrm{N}, 70^{\circ}-90^{\circ} \mathrm{E}\right)$ are indeed well correlated (corr: 0.72 for 1979-2006).

Linear regressions such as the one for Fig. 4a have been done for various periods of the summer: JuneSeptember, June-August, July-August, and the independent July and August periods. They all give a similar pattern of correlated/regressed SST in the upwelling region, even if the strong intraseasonal variability of the monsoon-which is controlled by other processes (Mathew and Tanimoto 2007) — could have blurred the influence of upwelling SST on monsoon interannual variability when using monthly averages. The influence of upwelling SST interestingly peaks in July-August (see appendix $\mathrm{C}$ on this seasonal phase locking). Conversely, both the mechanism and the SST-precipitation relationship are different for the monsoon onset in May (see discussion in appendix $\mathrm{C}$ ).

\section{2) AsSOCIATED MOISTURE TRANSPORT VARIATIONS}

To estimate the related moisture transport variations, moisture transport was regressed with west Indian monsoon rainfall in June-August (Fig. 4c). The increase in west Indian monsoon rainfall is associated with an increase in moisture transport over the Arabian Sea toward the Western Ghats in the lower troposphere. This is in agreement with the mechanism inferred from the model experiments. In July-August, when the mechanism has its maximal efficiency (see appendix C), low-level wind convergence also increases along the Indian west coast (not shown) owing to a CISK-like interaction between low-level moisture convergence and latent heat release, similar to what the model experiments showed.

An increase in moisture transport is also found in the Southern Hemisphere during summer with strong west Indian monsoon rainfall (Fig. 4c). Warm SST anomalies (see section 4 for their origins) over the SeychellesChagos thermocline ridge (Yokoi et al. 2008; Hermes and Reason 2008; Vialard et al. 2008), lasting until midsummer (Fig. 4a; Xie et al. 2002; Rao and Behera 2005; Vialard et al. 2008), favor evaporation (Terray et al. 2007) and may explain the moisture increase there. The moisture transport increase extends slightly into eastern Africa along the lower-tropospheric pathways. It may contribute partly to the increase in moisture of the air masses arriving on the western coast of India. However, a previous study (Ninomiya and Kobayashi 1999) showed that variations of cross-equatorial moisture transport from the Southern Hemisphere are significantly smaller than variations of moisture transport within a domain including the north Indian Ocean, India, and Southeast Asia.

\section{Sources of upwelling interannual variations}

In the previous section, with model experiments and observational analysis, the role of upwelling SST variations in west Indian monsoon rainfall variability was shown. We now investigate the causes of the observed year-to-year variations in summer SST over the western Arabian Sea: that is, how the preceding oceanic and atmospheric conditions lead to such SST variations, and hence influence monsoon interannual variability.

\section{a. Late spring conditions in the western tropical Indian Ocean}

\section{1) Wind Variability in the Western ARABian SEA}

Interannual variations of summer winds (black arrows in Figs. 4a and 4b) cannot explain the observed summer SST variations in the western Arabian Sea. The blue arrows in Figs. $4 \mathrm{a}$ and $4 \mathrm{~b}$ show winds in late spring (April-June) regressed respectively with west Indian monsoon rainfall and SST in the upwelling region the following summer. Before a summer with anomalously warm SST in the upwelling region and strong west Indian monsoon rainfall, southwesterly winds along the Somalia-Oman coasts are weaker than normal during late spring, especially during the monsoon onset period (correlations with monthly winds peak in May-early June; not shown). Such weakening causes a decrease in southwesterly wind stress, and thus in offshore Ekman transport and coastal upwelling. The decrease in wind speed also causes a latent heat flux decrease (Fig. 5). Both effects tend to warm the mixed layer.

To compare their relative importance, a rough estimate of their warming effects is necessary. We can consider here a mixed layer of depth $h_{\mathrm{ML}}$ extending around $10^{\circ} \mathrm{N}$ from the coast to a distance $L$ offshore. We can assume that the offshore southeastward Ekman transport $\left(\rho_{a} C_{D} V_{\mathrm{SW}}^{2} /\left(\rho_{w} f\right)\right)$ of warm water at temperature $T_{\text {surf offshore }}$ is balanced by upwelling of cold water at temperature $T_{\text {upw }}$ (with $\rho_{a}$ and $\rho_{w}$ the air and water densities, $C_{D}$ the drag coefficient, $f$ the Coriolis parameter, and $V_{\text {Sw }}$ the southwesterly 10-m wind speed). This circulation causes a cooling tendency of about $-\rho_{a} C_{D} V_{\mathrm{SW}}^{2} /\left(\rho_{w} f\right) \times\left(T_{\text {surf offshore }}-T_{\text {upw }}\right) /\left(L h_{\mathrm{ML}}\right){ }^{\circ} \mathrm{C}$ month ${ }^{-1}$. Using a typical value of $C_{D}$ in this region of 


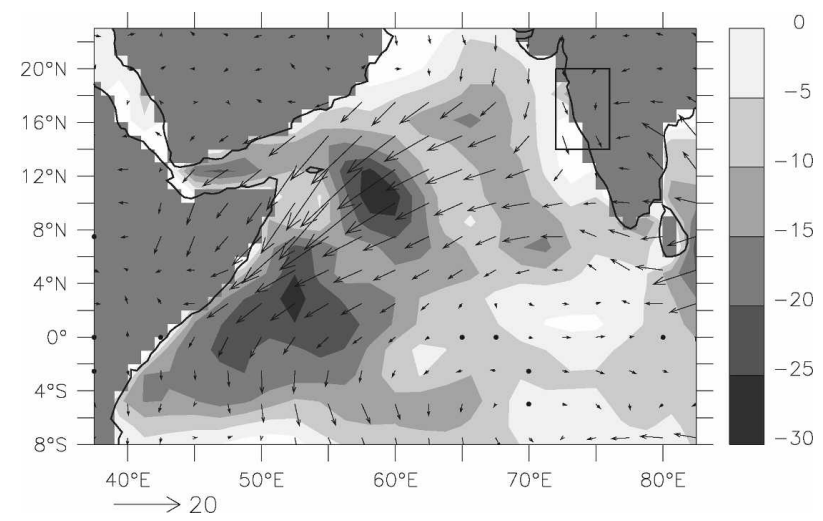

FIG. 5. Surface latent heat flux (shading) and pseudo-wind stress in late spring (from NCEP reanalysis) regressed with Indian west coast land precipitation (box) in summer (units: $\mathrm{W} \mathrm{m}^{-2}$ and $\mathrm{m}^{2} \mathrm{~s}^{-2}$ per $5 \mathrm{~mm}$ day $^{-1}$ ). A latent heat flux anomaly of $-20 \mathrm{~W}$ $\mathrm{m}^{-2}$ leads to a $0.7^{\circ} \mathrm{C}$ month ${ }^{-1}$ warming tendency in a 20 -m-depth mixed layer. Comparatively, a northeasterly wind stress anomaly of $20 \mathrm{~m}^{2} \mathrm{~s}^{-2}$ leads to a decrease in coastal upwelling and a warming tendency of at least $2^{\circ} \mathrm{C}$ month ${ }^{-1}$ within $500 \mathrm{~km}$ off Somalia coast (see section $4 \mathrm{a}$ ).

about $1.510^{-3}, \rho_{a} C_{D} /\left(\rho_{w} f\right)$ is about $1.910^{5} \mathrm{~m}^{2}$ month $^{-1}$ at $10^{\circ} \mathrm{N}$. The coastal upwelling is fed by the Somalia subsurface current with a transport-weighted temperature of about $15^{\circ}-20^{\circ} \mathrm{C}$ (Schott et al. 2002). With $T_{\text {upw }}$ about $15^{\circ}-20^{\circ} \mathrm{C}$ and $T_{\text {surf offshore }}$ about $25^{\circ} \mathrm{C}$, ( $\left.T_{\text {surf offshore }}-T_{\text {upw }}\right)$ is at least $5^{\circ} \mathrm{C}$. For $L=500 \mathrm{~km}$ and $h_{\mathrm{ML}}=20 \mathrm{~m}$, a pseudo-wind-stress anomaly $\left(\mathrm{V}_{\mathrm{Sw}}{ }^{2}\right)^{\prime}$ of about $-20 \mathrm{~m}^{2} \mathrm{~s}^{-2}$ (as in Fig. 5 east and northeast of Somalia) will cause a warming tendency anomaly on the order of at least $2^{\circ} \mathrm{C}$ month ${ }^{-1}$. For comparison, the latent heat flux $\left(F_{\text {lat }}\right)$ cooling tendency is $-F_{\text {lat }}$ t $\left(\rho_{w} C_{p} h_{\mathrm{ML}}\right)=-0.66 \times F_{\text {lat }} / h_{\mathrm{ML}}{ }^{\circ} \mathrm{C}$ month $^{-1}\left(C_{p}\right.$ being water heat capacity). For a decrease in latent heat flux of around $20 \mathrm{~W} \mathrm{~m}^{-2}$ (as in Fig. 5) and $h_{\mathrm{ML}}=20 \mathrm{~m}$, we will have a warming tendency anomaly of about $0.7^{\circ} \mathrm{C}$ month $^{-1}$. Hence, the upwelling influence on SST is at least three times larger than the latent heat flux influence from the Somalia coast to $L \sim 500 \mathrm{~km}$ offshore.

In any case, both mechanisms lead to the same effect: a SST warming in the western Arabian Sea after one to two months, the characteristic time inferred from the mixed layer heat budget analysis (see appendix B). The main summer SST pattern along the Somalia coast (Fig. 4a) associated with west Indian monsoon rainfall variability is however caused mostly by upwelling variations. Accordingly, June-August SST along Somalia (box in Fig. 4b) is highly correlated (corr: 0.73) to April-June northeasterly anomalies in the west Arabian Sea (box in Figs. 6a,b) with a regression slope of $0.34^{\circ} \mathrm{C} \mathrm{m}^{-1} \mathrm{~s}$. Note that preconditioning of the mixed layer depth by upwelling anomalies in early spring might also slightly influence summer SST. To conclude, the alongshore wind variability in the western Arabian Sea during late spring/monsoon onset is the main origin of summer upwelling SST variability, and consequently of west Indian monsoon rainfall interannual variability.

\section{2) Role of the Seychelles-Chagos THERMOCLINE RIDGE}

The weaker than normal southwesterly winds (i.e., northeasterly anomalies) in late spring over the western Arabian Sea are significantly related to warm SST and enhanced precipitation in the southwest Indian Ocean around $11^{\circ}-5^{\circ} \mathrm{S}, 45^{\circ}-60^{\circ} \mathrm{E}$ in the shallow thermocline ridge region (Figs. 6a,b). Because of the warm SST in spring, atmospheric convection and circulation are highly sensitive to relatively small SST variations over the region. Indeed, SST warming there causes a local increase in precipitation. Such response of precipitation to SST has been confirmed with an AGCM forced by SST anomalies over the thermocline ridge (Annamalai et al. 2005). Consequently, the northwestward migration of the intertropical convergence zone (ITCZ) is delayed, as well as the Indian monsoon onset (Fig. 6b) and the establishment of the Findlater jet. This delay creates an anomalous boreal winter monsoonlike wind circulation, and thus northeasterly wind anomalies over the Arabian Sea in late spring. Reversed regressions between SST/precipitation averaged over the thermocline ridge region and winds over the Indian Ocean have also been calculated to confirm such a link (not shown).

In agreement with the present chronological sequence, spring SST in the southwest Indian Ocean is found to be a potential predictor for west Indian monsoon rainfall: correlations (using March-May premonsoon SST) peak around $8^{\circ}-10^{\circ} \mathrm{S}, 50^{\circ}-55^{\circ} \mathrm{E}$ at 0.56 (significant at the $99 \%$ level) for west Indian monsoon rainfall and as much as 0.69 for the Indian rainfall dipole (see section 5a for its definition).

\section{b. Previous boreal winter conditions in the Indo-Pacific region}

\section{1) Rossby WAVES IN THE SOUTH TROPICAL INDIAN OCEAN}

We now investigate the causes of such SST/precipitation anomalies over the thermocline ridge in late spring. Around May, thermocline and mixed layer depth (see black contours in Fig. 7) reach their semiannual minima there (Reverdin 1987; Murtugudde and Busalacchi 1999; Yokoi et al. 2008). The subsurface influence on SST is high (Xie et al. 2002; Rao and Behera 

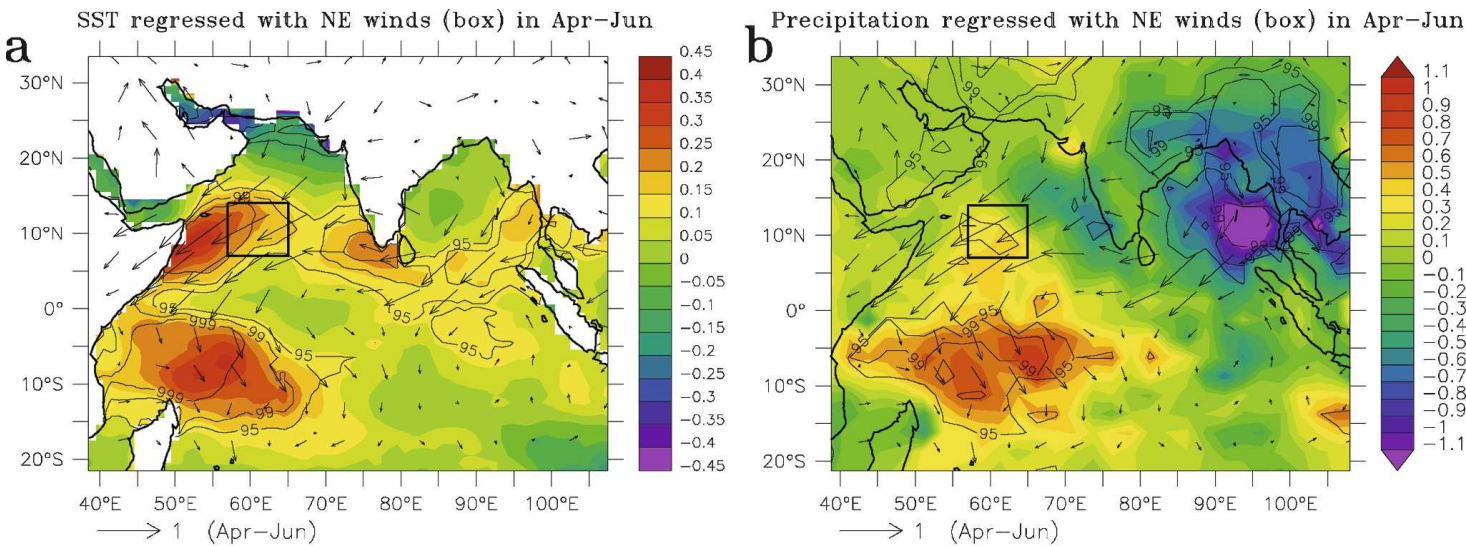

SST in late spring (Apr-Jun) regressed

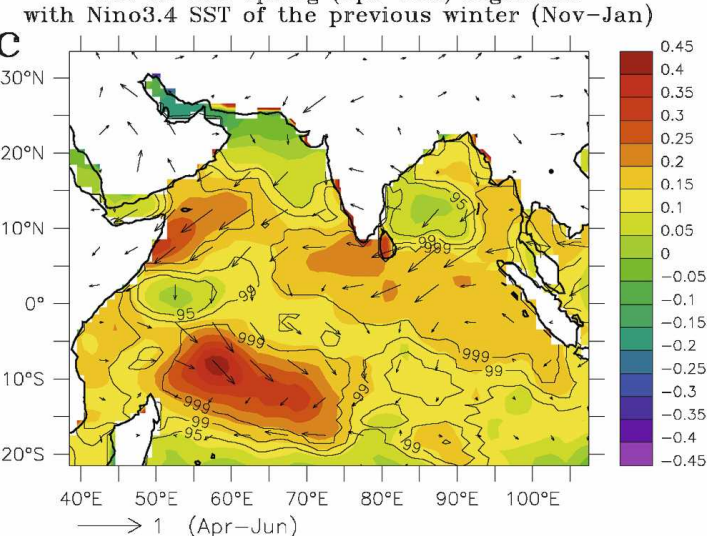

Precipitation in late spring (Apr-Jun) regressed

C

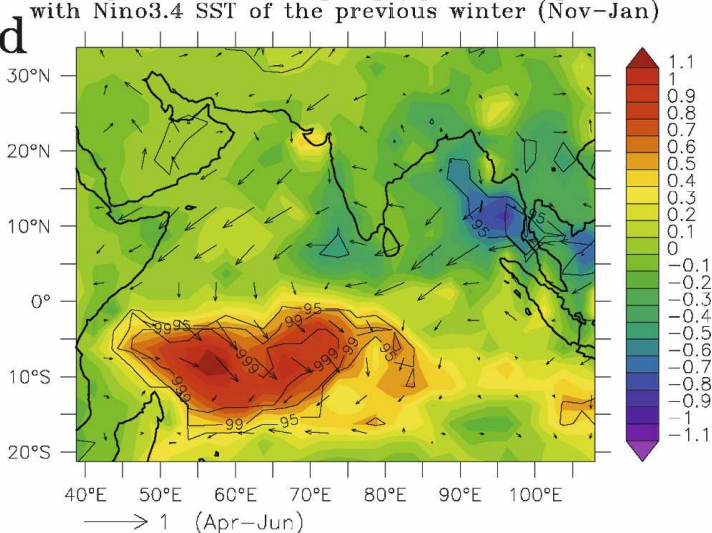

FIG. 6. Upwelling strength related to (a), (b) conditions in the western Indian Ocean in late spring and (c), (d) El Niño conditions of the previous winter: (left) April-June (AMJ) SST and winds (right) AMJ precipitation and winds regressed with (top) northeasterly winds in the west Arabian Sea (box) in late spring (AMJ) and (bottom) Niño-3.4 SST of the previous winter [November-January (NDJ); 5-months lag]. Black contours show the $95 \%$, $99 \%$, and $99.9 \%$ significance levels. Note a negative precipitation pattern on the west coast of India in (b) showing the late onset of monsoon rainfall caused by anomalous northeasterlies in the Arabian Sea (Halpern and Woiceshyn 2001). The well-known warming all over the Indian Ocean associated with El Niño (Yang et al. 2007) is observed in (c). Regression slopes units: ${ }^{\circ} \mathrm{C}$, mm day $^{-1}$, and $\mathrm{m} \mathrm{s}^{-1}$ per $1 \mathrm{~m} \mathrm{~s}^{-1}$ change in northeasterly winds over the western Arabian Sea [in (a) and (b)] or per a $1^{\circ} \mathrm{C}$ change in Niño-3.4 SST [(in (c) and (d)].

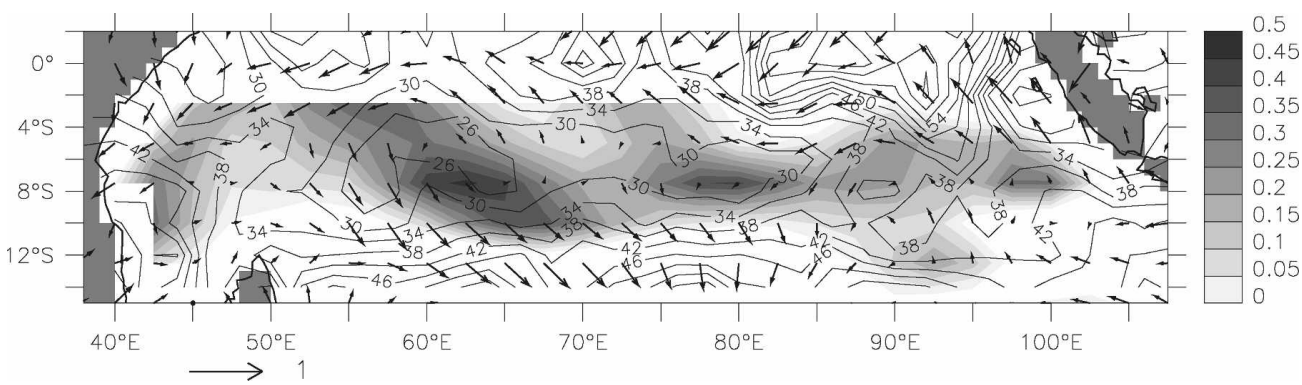

FIG. 7. Lag-correlation of wind stress (arrows) and Ekman downwelling south of $2^{\circ} \mathrm{S}$ (positive values shaded) during previous winter (DJF) with Indian west coast land precipitation (same box as in Figs. 4a,c) of the following summer (JJA). Climatological depth of the mixed layer in May is added to indicate the shallow thermocline ridge in late spring $(25-30 \mathrm{~m})$. Mixed layer depth (criteria T02: $\left.T_{10 \mathrm{~m}}-0.2^{\circ} \mathrm{C}\right)$ is implemented from de Boyer Montégut et al. (2004) climatology (new version using notably subsurface Argo data until 2006). 
2005). Late spring SST anomalies in the thermocline ridge region can hence be caused by off-equatorial oceanic Rossby waves created in the south Indian Ocean. These waves are mostly created by wind stress curl and associated Ekman pumping anomalies during the previous winter, and not by Kelvin wave eastern boundary reflection (Périgaud and Delecluse 1993; Masumoto and Meyers 1998; Rao and Behera 2005). The Rossby waves propagate slowly westward, sustained by a positive coupling (Xie et al. 2002). The anomalies in the thermocline ridge usually fade in June-July because of a negative coupling feedback (Xie et al. 2002) locked to the seasonal migration of the ITCZ.

Figure 7 shows which anomalies in wind stress curl and associated Ekman pumping during the previous winter are mostly correlated with the following west Indian monsoon rainfall. The latter rainfall is significantly correlated to Ekman downwelling in the previous winter over the southwest Indian Ocean, with maximal correlations around $10^{\circ}-5^{\circ} \mathrm{S}, 55^{\circ}-70^{\circ} \mathrm{E}$ (significant at the $95 \%$ level). The associated wind stress curl variations are caused by easterlies along the equator and by northwesterlies south of the thermocline ridge. Correlations are relatively high with respect to the uncertainties of NCEP reanalysis winds.

Why is the west Indian monsoon rainfall mostly influenced by previous winter anomalies of Ekman downwelling/upwelling around $10^{\circ}-5^{\circ} \mathrm{S}, 55^{\circ}-70^{\circ} \mathrm{E}$ ? As shown in section $4 \mathrm{a}$, the west Indian summer monsoon rainfall is mostly influenced by the alongshore wind anomalies in the western Arabian Sea in late spring. These are mostly caused by SST/precipitation anomalies in the southwest Indian Ocean centered around $11^{\circ}-5^{\circ} \mathrm{S}, 45^{\circ}$ $62^{\circ} \mathrm{E}$ (Figs. 6a,b). Taking into account the observed Rossby wave westward propagation of about $10^{\circ}-15^{\circ}$ per 4 months in this latitude band, these anomalies can be generated by Ekman pumping anomalies $10^{\circ}-15^{\circ}$ east of the crucial zone in winter. Interestingly, such Ekman pumping anomalies continue in spring (not shown), confirming the positive sustained coupling through air-sea interactions described by previous studies (Huang and Kinter 2002; Xie et al. 2002).

2) INFLUENCE OF El Niño AND INDONESIAN-AUSTRALIAN MONSOON VARIATIONS

ENSO is one of the most important sources of oceanic Rossby waves in the south tropical Indian Ocean during boreal winter. This interannual oscillation produces Rossby waves over a large longitudinal band of the south Indian Ocean in boreal winter and might thus influence the following summer Indian monsoon. During an El Niño, the convection and associated latent heat release over the Maritime Continent and eastern Indian Ocean is decreased, leading to an atmospheric response with a Matsuno-Gill pattern (Matsuno 1966; Gill 1980). This creates positive wind stress curl anomalies in winter/early spring in the south-central east Indian Ocean (Xie et al. 2002; Rao and Behera 2005; Huang and Shukla 2007a,b). These can create downwelling anomalies in the relatively narrow region shown in Fig. 7, favoring a strong west Indian monsoon rainfall through the aforementioned mechanisms.

In spring, the SST and precipitation anomalies over the thermocline ridge before strong west Indian monsoon rainfall (Figs. 6a,b) are indeed similar to the anomalies in spring associated with Niño-3.4 SST of the preceding winter (Figs. 6c,d). They are thus often related to prior El Niño conditions. Accordingly, previous September-November (December-January) [SON(DJF)] Niño-3.4 SST is significantly correlated with the west Indian monsoon rainfall [corr: 0.38(0.40)] and the Indian rainfall dipole [corr: $0.49(0.53)]$ of following JJA. These correlations are relatively high, despite the other factors than ENSO that might influence late spring winds along Somalia-Oman coasts.

Actually, the region of maximal influence in Fig. 7 is relatively narrow compared to the downwelling/upwelling anomalies created by ENSO over a larger $15^{\circ}-$ $5^{\circ} \mathrm{S}, 60^{\circ}-100^{\circ} \mathrm{E}$ region in winter (not shown). The narrow region can have other sources of interannual variability, particularly the Indonesian-Australian monsoon variations in boreal fall-winter, possibly related to the tropospheric biennial oscillation (TBO, see section $5 b$ ), and a priori also the IOD in fall (see section 5c). For instance, a weak Indonesian-Australian monsoon in boreal winter is associated with anomalous subsidence over the Maritime Continent, and hence also with equatorial easterlies and MatsunoGill pattern wind anomalies to its west. This causes positive wind stress curl and downwelling anomalies in the south tropical Indian Ocean in winter. The latter anomalies tend to be followed by strong west Indian summer monsoon rainfall (vice versa for a boreal winter with a strong Indonesian-Australian monsoon).

Accordingly, in observations, the CMAP precipitation of the previous boreal autumn(winter) [SON(DJF)] over Indonesia and Northern Australia $\left(15^{\circ} \mathrm{S}-0^{\circ}, 110^{\circ}-145^{\circ} \mathrm{E}\right)$ is significantly anticorrelated with the next summer west Indian monsoon rainfall $[-0.47(-0.40)]$ as well as with the Indian rainfall dipole $[-0.559(-0.52)]$. Fall-winter Indonesian-Australian monsoon anomalies seem to have thus as much influence as ENSO anomalies on the following west Indian monsoon rainfall. This reminds one that not only ENSO years but also non-ENSO years with anomalous 


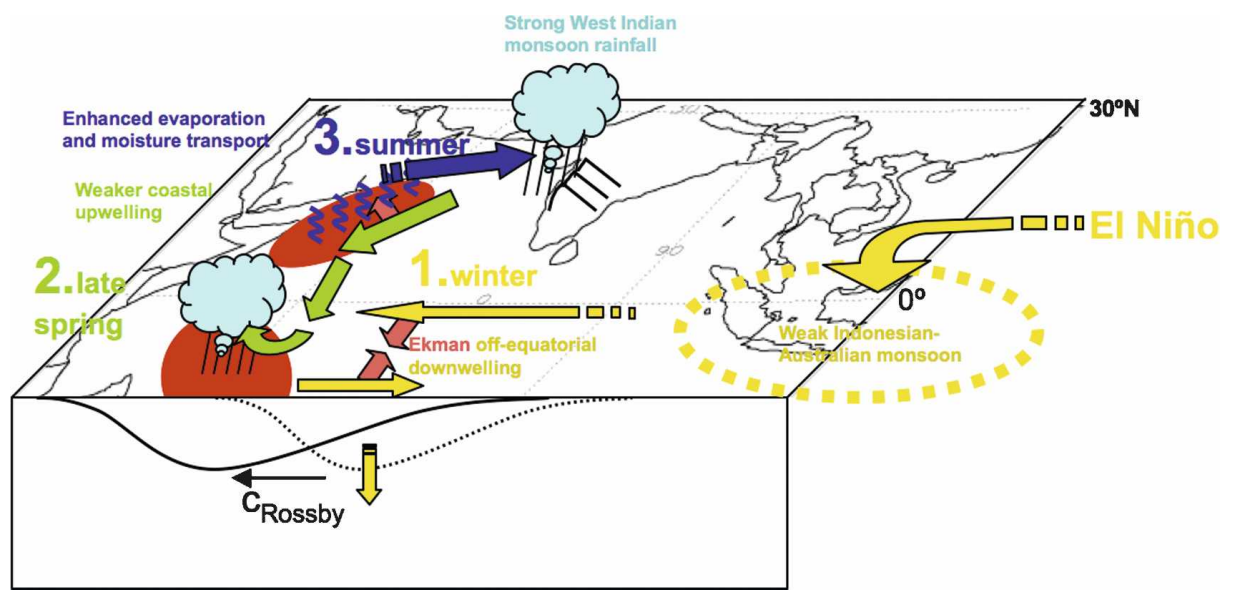

FIG. 8. Schematic diagram of the mechanism leading to strong west Indian monsoon rainfall (vice versa for weak west monsoon rainfall). 1) During the previous winter, anomalous Ekman transports (orange arrows), due to wind stress curl anomalies (yellow arrows; often related to El Niño conditions and/or a weak Indonesian-Australian monsoon; sections $4 \mathrm{~b}$ and 5b and Fig. 7), create off-equatorial downwelling Rossby waves in the southwest-central Indian Ocean. These waves slowly propagate toward the southwest Indian Ocean in about 4-5 months, 2) where they can create warm SST anomalies in late spring over the shallow thermocline ridge. These SST anomalies cause a local increase in precipitation. The northwestward migration of the ITCZ is delayed, as well as the monsoon onset and the establishment of the Findlater jet. This delay creates an anomalous boreal winter monsoonlike wind circulation, and thus northeasterly wind anomalies over the Arabian Sea during late spring/monsoon onset (green arrows). This causes weaker offshoreward Ekman transport (orange arrow) and coastal upwelling. 3) This in turn leads to warmer SST with a one to two month delay (see appendix B), so in summer. Finally, this increases evaporation (dark blue curls) in the western Arabian Sea and moisture transport (dark blue arrow) toward the Western Ghats (mountains), leading to enhanced precipitation along the Indian west coast.

autumn-winter Indonesian-Australian monsoon can modulate the following summer west Indian monsoon rainfall.

\section{c. Synthesizing the chronological sequence}

From the results evidenced above, a chronological sequence is presented in Fig. 8, with the involved mechanisms, all phase locked to the seasonal cycle. During the preceding boreal winter, wind stress curl anomalies, often related to an El Niño event and/or a weak Indonesian-Australian monsoon, cause downwelling anomalies that propagate slowly westward as oceanic Rossby waves, sustained by a positive coupling (Xie et al. 2002). Reaching the thermocline ridge in the southwest Indian Ocean where subsurface influence on SST is high, they enhance the SST and thus precipitation there. This causes northeasterly wind anomalies over the Arabian Sea and a weaker coastal upwelling in late spring, leading to warmer SST and enhanced west Indian monsoon rainfall in summer.

The sequence is consistent with previous studies that show ENSO-monsoon lag correlations (Pant and Rupa Kumar 1997; Vecchi and Harrison 2004) and composites (Rao and Behera 2005; Luo et al. 2005a) and the crucial role of the Indian Ocean in this lag relationship (Wu and Kirtman 2005). This sequence precisely explains why El Niño (La Niña) is often followed the next summer by strong (weak) west Indian monsoon rainfall.

\section{Discussion}

\section{a. Indian rainfall dipole}

The linear regression between the SST in the upwelling region and precipitation evidenced an Indian rainfall dipole (Fig. 4b). On the other hand, various large-scale factors can influence the rainfall over all of India (such as teleconnections with Pacific summer SST, Eurasian snow cover in spring). Their large-scale influence can be removed by calculating the difference between western and eastern Indian rainfall. An Indian rainfall dipole index can be defined as the difference between western $\left(11^{\circ}-21^{\circ} \mathrm{N}, 71^{\circ}-76^{\circ} \mathrm{E}\right)$ and northeastern $\left(17^{\circ}-27^{\circ} \mathrm{N}, 82^{\circ}-87^{\circ} \mathrm{E}\right)$ India rainfall (regions of the same $10^{\circ} \times 5^{\circ}$ area). When using this index instead of the west Indian monsoon rainfall, the correlations with the western Arabian Sea SST are significantly improved of about 0.1 to 0.15 units: from $0.65-0.7$ to 0.75 0.8 using land gauge precipitation, from $0.55-0.60$ to 

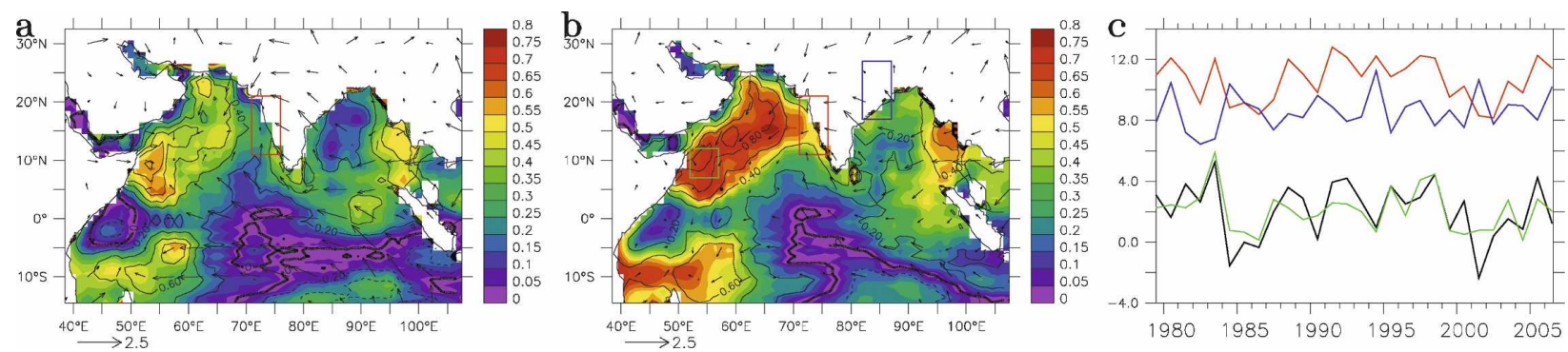

FIG. 9. Difference between west and east Indian monsoon responses to SST changes in the western Arabian Sea: evidence of an Indian rainfall dipole. Regressed SST (correlation in color, absolute value; slopes in contours) and winds (slopes in black arrows) in JJA (a) onto sea-land precipitation along the Indian west coast (red box) and (b) onto the precipitation difference between west and northeast Indian boxes (red box minus blue box) for JJA (units: ${ }^{\circ} \mathrm{C}$ and $\mathrm{m} \mathrm{s}^{-1}$ per $5 \mathrm{~mm}$ day ${ }^{-1}$ anomaly in precipitation). (c) Time series of sea-land precipitation in west (red line/box; corr. with SST: 0.58) and northeast (blue line/box; corr with SST: -0.46) India and the difference (Indian rainfall dipole; black line; corr with SST: 0.73 ) compared to SST in the upwelling region (green line/box; unit: $0.35^{\circ} \mathrm{C}$, with a $-25.2^{\circ} \mathrm{C}$ offset for easier comparison) for JJA. Note that Indian rainfall dipole is well correlated with Indian west coast rainfall [corr between Indian rainfall dipole and land precipitation over $14^{\circ}-20^{\circ} \mathrm{N}, 72^{\circ}-76^{\circ} \mathrm{E}$ (box in Figs. $4 \mathrm{a}, \mathrm{c}$ ): 0.70 ].

0.65-0.75 using sea-land CMAP precipitation over 1979-2006 (Fig. 9). Furthermore, the region of high correlation becomes much wider, extending over the entire western Arabian Sea. Hence, this index, being less influenced by other large-scale factors, emphasizes the regional role of Arabian Sea SSTs.

The difference in precipitation responses to SST of the upwelling region between western and northeastern India (Figs. 4b and 9) is consistent with the weak negative correlation between western Indian rainfall over the Western Ghats and northeastern Indian rainfall around the Ganges-Mahanadi basin observed by previous studies on interannual time scale (Shukla 1987; Rao and Goswami 1988; Vecchi and Harrison 2004). It shows the difference of behavior between the Arabian Sea and Bay of Bengal monsoon branches. This difference already exists for the monsoon onset, with its northward path along the Western Ghats, and its latter northwestward path in northeastern India along the Himalayan range.

Why do we have such a difference in response to the SST of the upwelling region? A mechanism can be proposed although a detailed study is beyond the scope of the present paper. A late spring decrease in the Somalia-Oman upwelling, by creating a summer warming of the western Arabian Sea, tends to increase precipitation along the west coast of India, as shown previously. But it also creates an anomalous cyclonic circulation centered on the precipitation increase in western India, and hence easterly anomalies north of this increase (Figs. 4a,c). This tends to decrease dynamically the monsoon westerly winds in the low troposphere over northern India, south of the Himalayan range. This leads to a decrease in moisture transport toward northeastern India (Fig. 4c) and hence in moisture convergence and precipitation there (Fig. 4b).

\section{$b$. Interaction with the tropospheric biennial oscillation}

The tropospheric biennial oscillation is an important mode of interannual variability in the Indo-Pacific, possibly interacting with both ENSO and IOD. The inphase transition of the TBO from a weak (strong) Indian summer monsoon to a weak (strong) Indonesiannorthern Australian autumn and winter monsoon is well understood as a large-scale southeastward displacement of the anomalous convection superimposed on its climatological seasonal cycle. It involves notably a coupling with the seasonal evolution of Pacific SST interannual anomalies (Meehl and Arblaster 2002a; Yu et al. 2003). It is often, but not always, associated with El Niño (La Niña) conditions (Meehl et al. 2003).

Conversely, the observed out-of-phase transition of the TBO from a weak (strong) Indonesian-Australian monsoon in boreal autumn-winter to a strong (weak) Indian monsoon in summer is only roughly understood. Various mechanisms were proposed, and their details vary with the studies that use observations composites analysis (Meehl and Arblaster 2001, 2002a; Meehl et al. 2003), theoretical models (Chang and Li. 2000; Li et al. 2001), and GCM experiments (Ogasawara et al. 1999; Loschnigg and Webster 2000; Meehl and Arblaster 2002b; Loschnigg et al. 2003; Yu and Lau 2005).

The sequence evidenced in the previous section (Fig. 8) gives a possible mechanism for the out-of-phase transition of the TBO between the Indonesian-Australian monsoon of the preceding boreal winter and the following Indian summer monsoon. In comparison to earlier TBO studies, the sequence involves precise seasonally phase-locked mechanisms acting in specific regions of the Indian Ocean. These results confirm and extend previous studies emphasizing the essential role of the 
Indian Ocean (Yu et al. 2003) and of the slowly westward propagating oceanic Rossby waves south of the equator (Meehl et al. 2003) ${ }^{2}$ in the out-of-phase transition of the TBO.

\section{c. Ambiguous influence of the Indian Ocean Dipole}

The Indian Ocean Dipole phenomenon peaks in fall and is an important mode of interannual variability at that season in the Indian Ocean. Interestingly, it does not seem to influence the following summer west Indian monsoon rainfall: the correlation is 0.03 with previous fall IOD index, whereas it is 0.38 , significant at the $95 \%$ level, with the previous fall Niño-3.4 SST. Why can the IOD not influence next summer west Indian monsoon rainfall?

As discussed previously, late spring SST/precipitation anomalies in the southwest Indian Ocean can influence summer SSTs and monsoon through SomaliaOman upwelling changes. The late spring anomalies are mostly caused by westward-propagating oceanic offequatorial Rossby waves. The Rossby waves generated by an Indian Ocean Dipole in fall are actually closer to the equator and propagate much faster $\left(c \sim 10^{\circ}\right.$ month $^{-1}$ at $\left.5^{\circ} \mathrm{S}\right)$ than those generated by ENSO or TBO in winter $\left(c \sim 3-4^{\circ}\right.$ month $^{-1}$ at $10^{\circ} \mathrm{S}$, see Rao and Behera 2005). Thus, the oceanic Rossby waves generated by IOD variability impact southwest Indian Ocean conditions only in winter and early spring and cannot influence following summer Indian rainfall.

The IOD during its developing phase in summer is somewhat correlated to the simultaneous west Indian monsoon rainfall (corr: +0.38 in JJA). However, this correlation is mostly due to the western pole of the IOD index (corr: +0.40 , whereas insignificant corr of -0.14 between the IOD eastern pole and the west Indian monsoon rainfall). Since the western pole $\left(10^{\circ} \mathrm{S}-\right.$ $10^{\circ} \mathrm{N}, 50^{\circ}-70^{\circ} \mathrm{E}$ ) includes parts of both Somalia upwelling region and Seychelles-Chagos thermocline ridge, this correlation may simply reflect the mechanism highlighted earlier in this study.

\section{d. Similarities and differences between model results and observational analysis}

The sensitivity experiment used here is a modeling approach to explore the impacts of changes in wind stress and Indian Ocean circulation on the summer monsoon. The change in the SENS numerical experi-

\footnotetext{
${ }^{2}$ However, the Meehl et al. (2003) study uses an observational analysis significantly different from the present study, based on composites of years with strong/weak all Indian monsoon rainfall averaged over a much larger spatial region within a shorter available period (1979-99).
}

ment is for the all Indian Ocean circulation. It has huge impacts on the Asian summer monsoon (Fig. 2d), as discussed in section 3a. In observations, the variations in wind stress that will influence the interannual variability of west Indian monsoon rainfall are actually northeasterly anomalies that only extend over the west and central Arabian Sea in late spring (section 4a). They modulate the western Arabian Sea upwelling regionally. These wind stress changes do not extend to the extreme north of the Arabian Sea and limit the upwelling and SST interannual anomalies to the western Arabian Sea, especially to the east-northeast of Somalia and southeast of Oman (Fig. 5). Hence, model and observational data analysis can be different and some notable spatial differences naturally exist between them.

Firstly, the strong warming in the east-northeast of the Oman coast and the warming (cooling) in the western (eastern) Bay of Bengal appearing in SENS experiment (Fig. 2c) are not seen in the regression analysis of Fig. 4a since these regions do not influence west Indian monsoon rainfall, which is our focus here. Secondly, the strong warming over $2{ }^{\circ} \mathrm{C}$ in the northwestern Arabian Sea in the SENS experiment (Fig. 2c) creates a violent increase in moisture over the usually dry PakistanRajasthan region (Fig. 3e), creating particularly abnormal precipitation (Fig. 2d) and cyclonic wind circulation there. In the observational analysis, the SST positive pattern extends less to the north (Fig. 4a), as discussed previously. It causes anomalous precipitation only over the eastern Arabian Sea and along the Indian west coast.

However, as discussed in sections $3 \mathrm{~b}$ and 4 , similarities between model and observational analysis are striking, with the same SST-evaporation-moisture transport-precipitation mechanism in summer and the same wind anomalies created by the CISK-like positive feedback. Moreover, the SST-winds-precipitation relationships obtained with the model experiments and through the observations regression analysis are remarkably of the same order. In particular, the monsoon rainfall response to a $1^{\circ} \mathrm{C}$ SST anomaly is about $5 \mathrm{~mm} \mathrm{day}^{-1}$, as in the CGCM.

\section{e. On the interdecadal (non)stationarity of the relationship between El Niño and Indian monsoon}

Intriguing long-term changes are observed in the relationships among Indian monsoon, ENSO, and SST in the Somalia-Oman upwelling region when using the few observations available. The correlation between the observed SST in this region and the west Indian monsoon rainfall during the $1948-78$ period is blurred 
by the lack of observations in the Somalia-Oman upwelling region before the satellite observations era, and possibly also by ENSO influence before the late 1970s climate shift (Nitta and Yamada 1989).

Lack of observations in the Somalia-Oman upwelling region before the satellite era can explain, at least partly, this absence of correlation. This region is in the vicinity of politically unstable countries; this makes missions at sea difficult. Moreover, the region has a high spatial and temporal mesoscale variability (Fischer et al. 2002), which increases the uncertainty in spatial and temporal averages of SST. For instance, a less precise spatial pattern and lower correlations are found for the regression analysis shown on Fig. 4a when using ERSST (Smith and Reynolds 2004) instead of OI SST data (Reynolds et al. 2002; more accurate, especially over the western Arabian Sea, free of cloud cover in summer).

To check this hypothesis, we can at least calculate the lag-correlation between previous winter El Niño and following summer Indian rainfall since ENSO indices such as Niño-3.4 SST are much better observed than the Somalia-Oman upwelling SST. We can use land precipitation data available since 1948 and define an Indian rainfall dipole over land (western India box: $10^{\circ}-$ $25^{\circ} \mathrm{N}, 65^{\circ}-80^{\circ} \mathrm{E}$; northeastern box: $18^{\circ}-28^{\circ} \mathrm{N}, 82^{\circ}-89^{\circ} \mathrm{E}$; larger regions are used to compensate observational lack and uncertainties). Interestingly, the lag relationship between previous winter El Niño (DJF Niño-3.4 SST) and Indian rainfall dipole (JJA) holds before the late 1970s and is rather stable interdecadally, with significant correlations of +0.50 and +0.57 for the 1948 76 and 1977-2006 periods, respectively. So the mechanisms and sequence presented in this study likely worked before 1979 but were partially blurred by the lack of observations in the Somalia-Oman upwelling region.

We should remind readers that, conversely, the wellstudied negative no-lag correlation between the all Indian rainfall and El Niño of the same year is unstable. The correlation is, for instance, -0.50 and -0.14 , respectively, for the 1948-76 and 1977-2006 periods (between JJA land precipitation averaged over $8^{\circ}-28^{\circ} \mathrm{N}$, $65^{\circ}-90^{\circ} \mathrm{E}$ and Niño-3.4 SST). This nonstationarity has been observed by numerous previous studies (Parthasarathy et al. 1991b; Pant and Rupa Kumar 1997; Ashok et al. 2001; Annamalai and Liu 2005). This nonstationarity may be due to changes in ENSO behavior and teleconnections before and after the climate shift (Krishna Kumar et al. 2006; Annamalai et al. 2007). It might also be due to interactions between ENSO biennial tendency and the lag relationship ENSO-monsoon discussed here. These could statistically lead to an un- stable negative no-lag correlation ENSO-monsoon, which could then be, at least partly, artificial (without any physical process involved).

\section{Conclusions and perspectives}

In this paper, we combined model experiments and observational analysis to study the role of the SomaliaOman upwelling on Indian monsoon interannual variability. The most striking results of this study are 1) anomalous warming of the southwestern Indian Ocean weakens the southwest Findlater jet and associated upwelling in late spring, and thus induces warming of the western Arabian Sea in summer; 2) the western Arabian Sea warming in turn induces increased summer rainfall along the Indian west coast (and vice versa for a year with a weak Indian west coast monsoon, see Fig. 8 for a schematic diagram). This contrasts with two prevailing ideas: (i) that warmer Arabian Sea SST would decrease the monsoonal winds by decreasing the land-sea thermal contrast that triggers the monsoon and (ii) that a decrease in southwesterly winds would lead to a weaker monsoon rainfall by decreasing moisture convergence. These latter mechanisms appear dominant for intraseasonal time scales (Cadet and Greco 1987) and for the onset of the monsoon (see appendix C) but not during the mature phase of the summer monsoon. A late (early) onset of monsoonal winds would even favor strong (weak) summer west Indian monsoon rainfall (see appendix C).

Furthermore, the southwestern Indian Ocean warming in spring over the Seychelles-Chagos shallow thermocline ridge is usually caused by intruding oceanic off-equatorial downwelling Rossby waves. These are created by anticyclonic wind stress curl anomalies in the south-central west Indian Ocean. These wind anomalies are often associated with El Niño and/or weak Indonesian-Australian monsoon conditions during the previous boreal winter. [These two phenomena are often, but not entirely related; see sections $4 b(2)$ and $5 b$.] The sequence evidenced here (Fig. 8) can thus explain the observed positive lag-correlation between previous winter El Niño conditions and the following Indian summer monsoon, as well as the out-of-phase transition between a weak (strong) winter Indonesian-Australian monsoon and the following strong (weak) Indian monsoon. The latter transition combines with the in-phase transition to create the tropical biennial oscillation.

The correlations found here between the thermocline ridge, upwelling and monsoon rainfall are high and statistically significant-despite the many other climatic factors that can influence the monsoon-with consistent results when using various independent observational products and various periods within the summer. 
They often explain more than $50 \%$ of rainfall interannual variance. Moreover, the western Arabian Sea summer SST could be seasonally predicted owing to the oceanic inertia, slow oceanic wave propagation, and seasonal phase-locking processes involved here. Hence, forecasting the Indian monsoon can be significantly improved by taking into account the influence of the Somalia-Oman upwelling. Concretely, precipitation is much more biased and difficult to forecast in CGCMs than SST. A CGCM with good SST predictability skills could accurately forecast a monsoon predictor based on SST, such as the SST in spring over the thermocline ridge region (high corr with west Indian monsoon: 0.7; see section 4a), or directly forecast SST in summer in the western Arabian Sea upwelling region. Actually, SST over the thermocline ridge in March-June can be predicted up to 12 months lead (Luo et al. 2005a, 2007; Schott et al. 2008). These SST seasonal forecasts could then be used to predict the west Indian monsoon rainfall and Indian rainfall dipole of the following summer, on account of the mechanisms discussed here.

With respect to the previous studies on large-scale monsoon that used indices such as the all-Indian rainfall (Mooley and Parthasarathy 1984), the present results focus on the west Indian monsoon rainfall, distinguishing it from the east Indian monsoon. These results emphasize the Indian monsoon complexity and the need to focus on monsoon regional characteristics rather than to simply use large-scale monsoon rainfall indices (consistent with Pant and Rupa Kumar 1997; Vecchi and Harrison 2004). Regional differences also exist for the intraseasonal variability of the Indian monsoon, with local air-sea interactions appearing dominant over the eastern Arabian Sea on the shorter intraseasonal time scale, especially during the monsoon onset (Mathew and Tanimoto 2007). Better understanding of the Indian rainfall dipole variability and the involved ocean-atmosphere interactions (section 5a), together with the possible role of interactions between intraseasonal and interannual monsoon variations, is a natural perspective of the present work.

Concerning ocean dynamics, the Somalia upwelling strongly interacts with the highly energetic features of the area, such as the Somalia current and the Great Whirl (Schott and McCreary 2001). An ongoing work actually focuses on quantifying the mechanisms of SST interannual variability in the region (C. de Boyer Montégut et al. 2008, unpublished manuscript). The present study also suggests that the shallow meridional overturning cross-equatorial cell (CEC) (Schott and McCreary 2001; Schott et al. 2002), which feeds the Somalia-Oman upwelling, can influence the monsoon. Decadal changes in CEC mass transport have been ob- served (Lee 2004; Schoenefeldt and Schott 2006). These CEC variations can change the internal structure of the ocean, preconditioning the thermocline depth/heat content and hence SST in the upwelling region. Long-term changes in temperature and associated spiciness anomalies of waters brought by the CEC might also be important, especially in the climate and Indian Ocean warming context. This has not been yet studied because of the lack of observations. This could be investigated in the future, thanks to the developments of observing systems such as Argo floats and improved OGCMs and CGCMs.

The Somalia-Oman upwelling strongly influences the biological activity in the Arabian Sea (Lévy et al. 2007). Interannual variations of the upwelling strength have already been evidenced through productivity variations in the Arabian Sea (Goes et al. 2005). Hence, recent and future in situ and satellite biological measurements could give useful information on the Somalia-Oman upwelling. Moreover, the biological activity might interact with SST through changes in water opacity, and could be taken into account in future GCMs.

The Indian Ocean experienced a basinwide warming in the last decades, possibly associated with decadal fluctuations and/or global warming (Lee 2004; Terray and Dominiak 2005; Alory et al. 2007). This warming could continue in the future. The present results shed new light on the expected changes of the Indian summer monsoon in response to any warming in the western Arabian Sea, and thus on the ambivalent effect of global warming on the monsoon (Annamalai et al. 2007).

Most of the observational analyses were done here for the last 28-yr period 1979-2006. Considering long time scales, we observed actually intriguing long-term changes in the relationships among the Indian monsoon, ENSO, and SST in the region influenced by Somalia-Oman upwelling (section 5e). Lack of observations in this region appears to be one of the reasons. Strikingly, the positive lag-correlation between previous boreal winter El Niño and west Indian summer monsoon rainfall, as well as with the Indian rainfall dipole, remains stable interdecadally over the 19482006 period of nearly 60 years, whereas the simultaneous negative correlation between the Indian summer monsoon and El Niño is unstable. This raises the question whether the latter relationship, supposedly due to atmospheric teleconnections, is entirely physical or partly statistical, possibly blurred by the lag relationship with west Indian monsoon rainfall. Interdecadal changes also exist in the SINTEX-F CGCM, as well as in other climate models (Kitoh 2007). Understanding such apparent changes in ocean-atmosphere interac- 

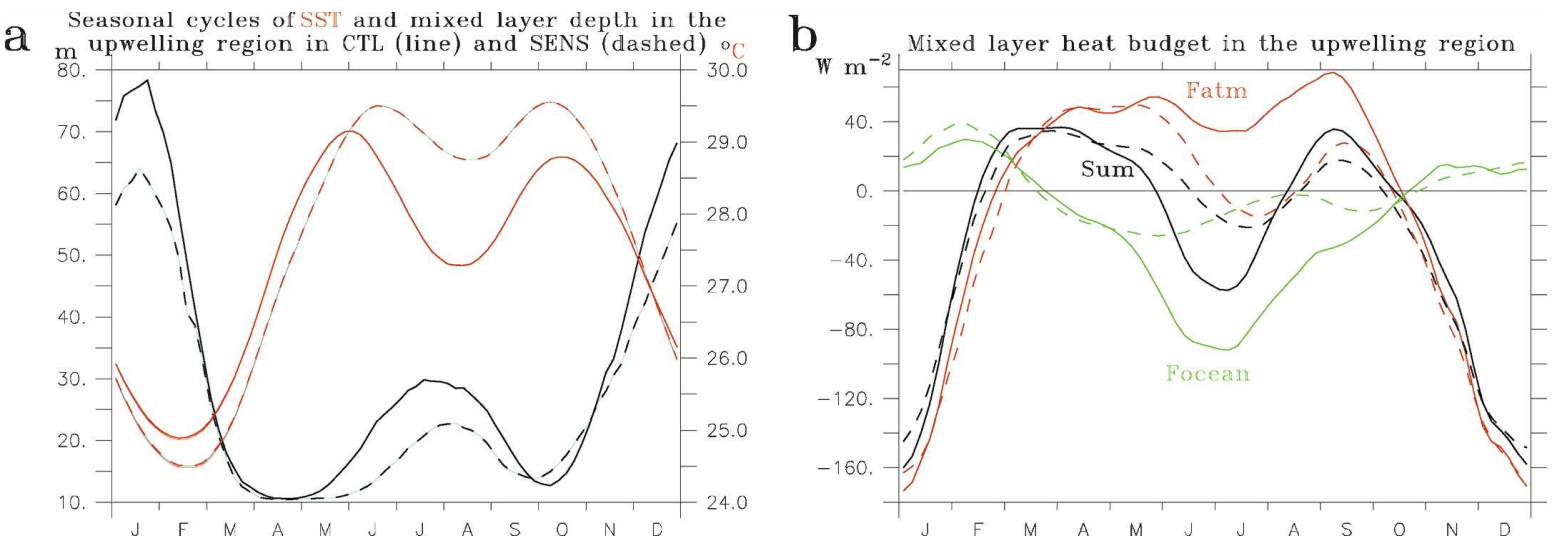

FIG. A1. Analysis of oceanic changes in SENS compared to CTL in the upwelling region. Seasonal cycles in CTL (plain line) and SENS (dashed line) of (a) SST (red, ${ }^{\circ} \mathrm{C}$ ) and mixed layer depth (black, $\mathrm{m}$ ) and (b) mixed layer heat budget (W $\mathrm{m}^{-2}$, total oceanic flux in green, atmospheric flux in red, and their sum, which corresponds to the temporal derivative of the mixed layer heat content, in black).

tions and climate variations is of primary interest to improve monsoon predictability.

All these results emphasize the importance of implementing ocean-atmosphere observing/modeling systems for the entire tropical Indian Ocean, including its western part. For example, the recent VASCO-Cirene program (Vialard et al. 2008; Duvel et al. 2008) and associated field experiment in January-February 2007 evidenced a nice example of strong downwelling Rossby waves in the Seychelles-Chagos thermocline ridge, which likely played a role in the $\sim 30 \%$ higher than normal rainfall over the Western Ghats observed during the following summer, 2007. Our ability to predict the monsoon will depend not only on our knowledge of large-scale conditions, but also on an accurate estimate of the state of the Indian Ocean on a regional scale.

Acknowledgments. The authors thank Dr. Gurvan Madec and Dr. Pascale Delecluse for fruitful discussions, and Pr. Shukuro Manabe for useful comments, as well as anonymous reviewers whose comments helped to improve this manuscript. We are also very grateful to Dr. Adam Clayton for his great kindness and help in improving manuscript English readability. The authors thank JAMSTEC, especially FRCGC and the Earth Simulator Center, for their great hospitality and the highest-performance material and computer facilities they offer. Dr. Sophie Cravatte, Dr. Fabien Durand, Dr. Jerome Vialard, and all the LEGOS and LOCEAN teams are greatly thanked for their support of this research project. Most of the observations data were made available mainly by NOAA/NCEP/CPC through Climate Diagnostics Center (CDC) and IRI/LDEO Climate Data Library servers. QuikScat data are produced by Remote Sensing Systems and sponsored by the
NASA Ocean Vector Winds Science Team. Those data were obtained from the IFREMER (CERSAT) ftp server. Some of the rainfall data used in this study were acquired as part of the Tropical Rainfall Measuring Mission (TRMM; sponsored by Japan NASDA and U.S. NASA Office of Earth Sciences, and distributed by the Goddard Distributed Active Archive Center). The authors also wish to acknowledge the use of NOAA/PMEL Ferret program for analysis and graphics in this paper, as well as to thank Dr. Pascal Terray for the use of Statpacks, the statistical analysis package he developed. This work was mostly funded by the Japan Society for the Promotion of Science (JSPS), and partly by the Institut Pierre-Simon Laplace (IPSL).

\section{APPENDIX A}

\section{Heat Budget of the Mixed Layer in the Upwelling Region}

A heat budget of the oceanic mixed layer in the upwelling region is computed to understand the change in SST in SENS experiment. The upwelling region is defined following the study of de Boyer Montégut et al. (2007): north of $6^{\circ} \mathrm{N}$ along Somalia and Oman coasts with an offshore width of about $400-500 \mathrm{~km}$. Figure A1a shows the seasonal cycles of SST and mixed layer depth in the upwelling region. The mixed layer heat budget is shown in Fig. A1b with the total oceanic flux in green, the atmospheric flux in red, and their sum in black. As expected, the oceanic cooling caused by upwelling from May to October is reduced in the SENS experiment (green in Fig. A1b), leading to a warmer SST in the SENS experiment than in the CTL experiment from June to November (red in Fig. A1a, with a lag due to thermal inertia; see appendix B). Hence, the 
atmospheric flux is lower in SENS from June to November (red in Fig. A1b), acting as a damping to the SENS - CTL SST difference through latent heat flux/ evaporation changes (see Fig. 3d for spatial patterns of these changes).

\section{APPENDIX B}

\section{Calculation of the Characteristic Time of Response of the Mixed Layer}

The time of response of the mixed layer temperature can be empirically calculated using the mixed layer heat budget of the coupled model (Fig. A1). The coupled model integrates complex bulk formulae and is a simple means to obtain the mixed layer temperature trend caused by an upwelling anomaly in the western Arabian Sea.

For instance, in July the $1.5^{\circ} \mathrm{C}$ SST warming in SENS (compared to CTL) leads to an enhancement in evaporation/latent heat flux toward the atmosphere of about $50 \mathrm{~W} \mathrm{~m}^{-2}$ in the upwelling region defined in Fig. A1b. This corresponds to a temperature trend anomaly of $-1.2^{\circ} \mathrm{C}_{\text {month }^{-1}}$ in the $\sim 30 \mathrm{~m}$ mixed layer. The associated atmospheric damping rate $1 / \tau$ is thus 0.8 month $^{-1}$ (see de Boyer Montégut et al. 2007 for a detailed presentation of the mixed layer temperature equation). Consequently, the response characteristic time $\tau$ of the SST to an upwelling anomaly will be $\sim 1.3$ month. Concretely, it will be between 1 and 2 months, depending on the temporal structure of the anomaly. For example, a constant positive anomaly of SST-precipitation appearing suddenly in May in the southwest Indian Ocean will create a sudden constant winter monsoonlike anomalous atmospheric circulation. This will be associated with a Heaviside steplike constant northeasterly wind anomaly appearing in May in the western Arabian Sea. It will cause a wind stress anomaly increasing linearly in May-mid-June (first-order approximation; see Fig. C2b). Such anomaly will lead to a SST warm anomaly with a response characteristic time 1.5-2 times larger than $\tau$ (which is the characteristic time associated with a Heaviside steplike anomaly in wind stress).

Using such calculation, the mixed layer temperature response to upwelling changes is rapid in April-May, with a response time of about half a month, because of the very thin mixed layer (thickness $\sim 15 \mathrm{~m}$ ) in the western Arabian Sea upwelling region at that period. The SST in May is hence influenced mostly by upwelling changes 0.5 to 1 month before, so in April-mid May. The SST response time increases in June to about 1 month, in July to 1.5 month, and in August to 2 months. Accordingly, lag-correlation analysis using monthly pe-

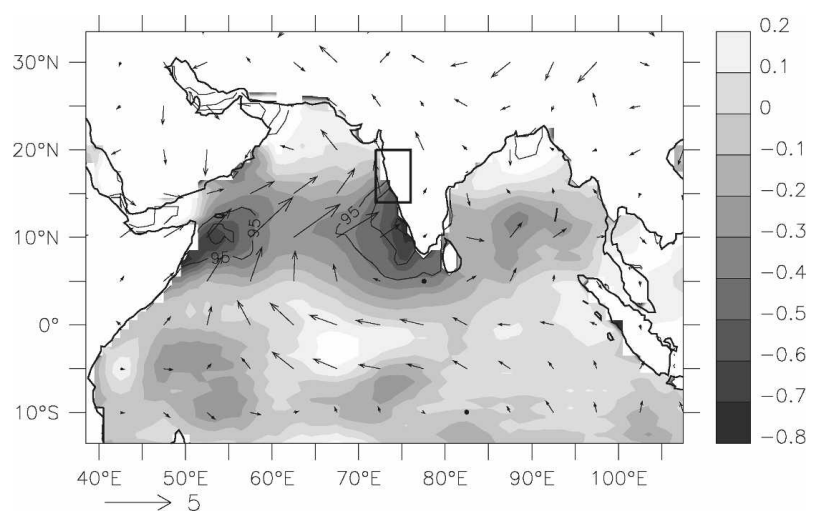

FIG. C1. Difference between the onset and the mature phase of the Indian monsoon. SST (gray shades) and 10-m winds (arrows) regressed with land precipitation (PREC/L, in box) in May (units: ${ }^{\circ} \mathrm{C}$ and $\mathrm{m} \mathrm{s}^{-1}$ per $5 \mathrm{~mm}$ day $^{-1}$ ): Black contours show the $95 \%$, $99 \%$, and $99.9 \%$ significance levels. The southwesterly wind anomalies cause a rapid cooling off Somalia and Oman shores, explaining the negative SST pattern seen there. The other cold SST pattern in the mini warm pool in the southeastern Arabian Sea is likely an oceanic response to enhanced precipitation and cloud cover along the Indian west coast.

riods showed that SST interannual anomalies in the upwelling region in May, June, July, and August are maximally lag-correlated with northeasterly anomalies in the western Arabian Sea about, respectively, 0-0.5, 1, $1-2$, and 2 months before. When averaging this SST over the June-August 3-month period and doing the lagged correlation with the March-May, April-June, May-June, and May-July periods, the maximal correlations are accordingly found for the April-June (corr: 0.73) and May-June (corr: 0.71) periods. This is in agreement with a 1.5-2-months average response time of the summer SST to late spring wind anomalies in the western Arabian Sea.

To summarize, the time of response of the mixed layer temperature is proportional to the mixed layer depth, hence varying from about 0.5 in May to 2 months in August.

\section{APPENDIX C}

\section{Seasonal Phase Locking of Upwelling Influence on the Monsoon}

Fundamental differences exist between the onset and the mature phase of the monsoon. Although the west Indian monsoon rainfall is controlled by SST during the mature phase (Fig. 4; section 3b), it is mostly controlled by winds during the onset (Fig. C1): in May, stronger than normal precipitation is not associated with SST changes in the upwelling region (low correlation, even negative) but is related to stronger southwesterly 

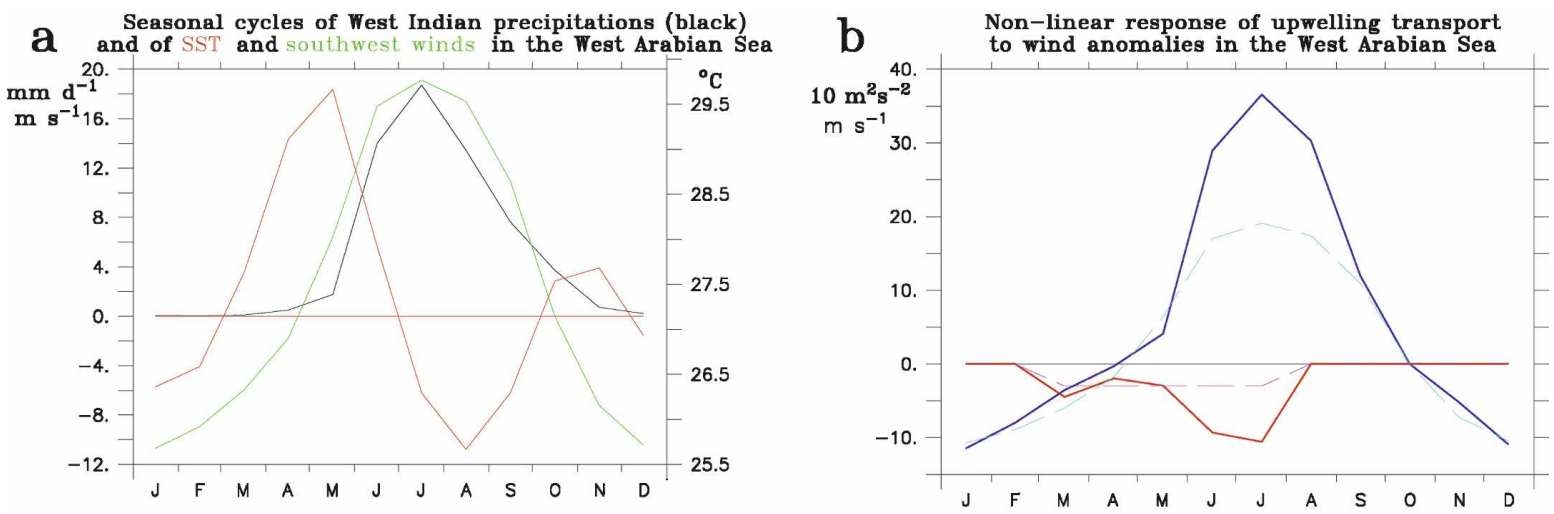

FIG. C2. Understanding the difference between onset and mature phase seasonal phase locking of the influence of upwelling anomalies on the monsoon variability: (a) Seasonal cycles of Indian west coast precipitation $\left(14^{\circ}-20^{\circ} \mathrm{N}, 72^{\circ}-76^{\circ} \mathrm{E}, \mathrm{black}^{\circ}\right.$, mm day $\left.{ }^{-1}\right)$ and of SST (red, ${ }^{\circ} \mathrm{C}$ ) and southwesterly winds (green, $\left.\mathrm{m} \mathrm{s}^{-1}\right)$ in the western Arabian Sea in the upwelling region $\left(5^{\circ}-15^{\circ} \mathrm{N}, 50^{\circ}-60^{\circ} \mathrm{E}\right) ;(\mathrm{b})$ Nonlinear response of upwelling transport to wind anomalies. Climatological southwesterly winds $\left(V_{\mathrm{Sw}}\right.$, light blue dashed line, $\left.\mathrm{m} \mathrm{s}^{-1}\right)$ and pseudo-wind stress (unit: $10 \mathrm{~m}^{2} \mathrm{~s}^{-2}$; dark blue thick line) in the upwelling region $\left(5^{\circ}-15^{\circ} \mathrm{N}, 50^{\circ}-60^{\circ} \mathrm{E}\right)$. An idealized constant northeasterly wind anomaly lasting from March to July $\left(V_{\mathrm{SW}}^{\prime}=-3 \mathrm{~m} \mathrm{~s}^{-1}\right.$; purple dashed line) leads to a seasonally varying anomaly of northeasterly pseudo-wind stress (red thick line). Note that pseudo-wind stress refers in this figure to square wind proportional to wind stress and with the same direction: $V_{\mathrm{SW}}^{3} /\left|V_{\mathrm{Sw}}\right|$.

winds. Why is there such a difference? A careful examination of the seasonal cycles is required to understand such seasonal phase locking and why mechanisms at work vary with the season.

SST and wind seasonal cycles are essential for latent heat flux. In July-August, SST is relatively cold and winds are uniformly strong over the region influenced by the western Arabian Sea upwelling (Figs. 1b and $\mathrm{C} 2 \mathrm{a})$. Hence, the latent heat flux/evaporation in the western Arabian Sea is well controlled by SST and warm pool extent, and the mechanism discussed in section 3 can work efficiently in summer (Fig. 4a). Conversely, in April-May, the warm pool is at its warmest and largest extent. SSTs are over $28^{\circ} \mathrm{C}$ for the entire Indian Ocean from about $20^{\circ} \mathrm{S}$ to $20^{\circ} \mathrm{N}$, even peaking over $30^{\circ} \mathrm{C}$ in some regions (Figs. 1a and $\mathrm{C} 2 \mathrm{a}$ ), and southwesterly winds are very weak (transition from the winter to summer monsoon wind regimes). Thus, in April-May, the latent heat flux is mostly limited by winds. Furthermore, the weak winds limit the weak moisture supply toward India.

The nonlinear response of the upwelling transport to wind anomalies also creates a seasonal phase locking. Wind anomalies in April-May will only create weak wind stress anomalies and associated upwelling transport anomalies because of weak mean winds, as evidenced by an idealized example (Fig. C2b). A constant northeasterly wind anomaly $\left(V_{\mathrm{sw}}^{\prime}\right)$ leads to seasonally varying anomalies in northeasterly wind stress (proportional to wind square: $\left.V_{\mathrm{sw}}^{3} /\left|V_{\mathrm{sw}}\right|\right)$, offshoreward Ekman transport and associated coastal upwelling. These latter anomalies are weak in April and increase strongly until summer. Hence, they generate weak SST anomaly in May (fast mixed layer response time $\sim 0.5-1$ month, see appendix B). Conversely, from mid May to summer, they are important and can thus have strong impact on June-August SST in the western Arabian Sea (especially on July-August SST because of the longer 1-2months response time, see appendix B). This evidences the seasonal phase locking of upwelling sensitivity to wind anomalies: wind anomalies can generate important SST anomalies in summer, but not around May.

For these reasons, in May, moisture convergence along the west coast of India and the related rainfall are mostly controlled by southwesterly wind anomalies (Fig. C1). The latter enhance the moisture convergence partly by increasing evaporation (through surface wind speed increase) and thus specific humidity $\left(q^{\prime} V_{\text {clim }}\right)$, but mostly by directly increasing moisture transport $\left(q_{\text {clim }} V^{\prime}\right)$. Hence, for the premonsoon rainfall and the onset of the monsoon, the usual idea that increased southwesterly winds bring more moisture toward India and thus favor precipitation is reasonable, in agreement with Halpern and Woiceshyn (2001).

A detailed analysis for each month has been done. In June, both SST and wind changes in June influence rainfall variations. In July, and especially in August when SST is at its lowest, the influence of upwelling SST anomalies on the west Indian monsoon rainfall is at its strongest, as confirmed by correlations between 
SST and rainfall calculated for each month (not shown).

This analysis is consistent with, and complements, earlier studies. Different behavior has been observed for the onset (delayed) and for the mature phase (enhanced) of the Indian summer monsoon following an El Niño event (Joseph et al. 1994) or southeast Indian Ocean warm SST anomalies in boreal winter (Terray et al. 2007). Arpe et al. (1998) also evidenced opposite interannual variations of northwest Indian rainfall for May and for summer, with Arabian Sea SST variations playing an important role.

\section{REFERENCES}

Alory, G., S. Wijffels, and G. Meyers, 2007: Observed temperature trends in the Indian Ocean over 1960-1999 and associated mechanisms. Geophys. Res. Lett., 34, L02606, doi:10.1029/2006GL028044.

Annamalai, H., and R. Murtugudde, 2004: Role of the Indian Ocean in regional climate variability. Earth's Climate: The Ocean-Atmosphere Interaction, Geophys. Monogr., Vol. 147, Amer. Geophys. Union, 213-246.

— to changes in El Niño properties. Quart. J. Roy. Meteor. Soc., 131, 805-831.

— active and break phases of boreal summer intraseasonal (3050 day) variability. J. Atmos. Sci., 62, 2726-2748.

— variability: Its local effect and remote influence on Asian monsoons. J. Climate, 18, 4150-4167.

—, K. Hamilton, and K. R. Sperber, 2007: South Asian summer monsoon and its relationship with ENSO in the IPCC AR4 simulation. J. Climate, 20, 1071-1092.

Arpe, K., L. Dümenil, and M. A. Giorgetta, 1998: Variability of the Indian monsoon in the ECHAM3 model: Sensitivity to sea surface temperature, soil moisture, and the stratospheric quasi-biennial oscillation. J. Climate, 11, 1837-1858.

Ashok, K., Z. Y. Guan, and T. Yamagata, 2001: Impact of the Indian Ocean Dipole on the relationship between the Indian monsoon rainfall and ENSO. Geophys. Res. Lett., 28, 44994502.

Behera, S. K., J.-J. Luo, S. Masson, S. A. Rao, H. Sakuma, and T. Yamagata, 2006: A GCM study on the interaction between IOD and ENSO. J. Climate, 19, 1688-1705.

Brock, J., and C. McClain, 1992: Interannual variability in phytoplankton blooms observed in the northwestern Arabian Sea during the southwest monsoon. J. Geophys. Res., 97 (C1), 733-750.

Cadet, D. L., and S. Greco, 1987: Water-vapor transport over the Indian Ocean during the 1979 summer monsoon. Part I. Water vapor fluxes. Mon. Wea. Rev., 115, 653-663.

Chang, C.-P., and T. Li, 2000: A theory of the tropical tropospheric biennial oscillation. J. Atmos. Sci., 57, 2209-2224.

Charney, J. G., and A. Eliassen, 1964: On the growth of the hurricane depression. J. Atmos. Sci., 21, 68-75.

Chen, M. Y., P. P. Xie, J. E. Janowiak, and P. Arkin, 2002: Global land precipitation: A 50-yr monthly analysis based on gauge observations. J. Hydrometeor., 3, 249-266.

de Boyer Montégut, C., G. Madec, A. S. Fischer, A. Lazar, and D.
Iudicone, 2004: Mixed layer depth over the global ocean: An examination of profile data and a profile-based climatology. J. Geophys. Res., 109, C12003, doi:10.1029/2004JC002378.

, J. Vialard, S. S. Shenoi, D. Shankar, F. Durand, C. Ethé, and G. Madec, 2007: Simulated seasonal and interannual variability of mixed layer heat budget in the northern Indian Ocean. J. Climate, 20, 3249-3268.

Duvel, J.-P., H. Bellenger, C. Basdevant, G. Reverdin, A. Vargas, and J. Vialard, 2008: The Aeroclipper: A new device to explore convective systems and cyclones. Bull. Amer. Meteor. Soc., in press.

Findlater, J., 1969: A major low-level air current near the Indian Ocean during the northern summer. Quart. J. Roy. Meteor. Soc., 95, 362-380.

Fischer, A. S., R. A. Weller, D. L. Rudnick, C. C. Eriksen, C. M. Lee, K. H. Brink, C. A. Fox, and R. R. Leben, 2002: Mesoscale eddies, coastal upwelling, and the upper-ocean heat budget in the Arabian Sea. Deep-Sea Res. II, 49, 2231-2264.

Gadgil, S., M. Rajeevan, and R. Nanjundiah, 2005: Monsoon prediction-Why yet another failure? Curr. Sci., 88, 1389-1400.

Gill, A. E., 1980: Some simple solutions for heat-induced tropical circulation. Quart. J. Roy. Meteor. Soc., 106, 447-462.

Goes, J. I., P. G. Thoppil, H. R. Gomes, and J. T. Fasullo, 2005: Warming of the Eurasian landmass is making the Arabian Sea more productive. Science, 308, 545-548.

Hahn, D. G., and J. Shukla, 1976: An apparent relationship between Eurasian snow cover and Indian monsoon rainfall. $J$. Atmos. Sci., 33, 2461-2462.

Halpern, D., and P. M. Woiceshyn, 2001: Somali jet in the Arabian Sea, El Niño, and India rainfall. J. Climate, 14, 434-441.

Hermes, J. C., and C. J. C. Reason, 2008: Annual cycle of the South Indian Ocean (Seychelles-Chagos) thermocline ridge in a regional ocean model. J. Geophys. Res., 113, C04035, doi:10.1029/2007JC004363.

Holton, J. R., 1992: An Introduction to Dynamic Meteorology. 3rd ed. Academic Press, 511 pp.

Huang, B., and J. L. Kinter, 2002: Interannual variability in the tropical Indian Ocean. J. Geophys. Res., 107, 3199, doi:10.1029/2001JC001278.

— ability in the tropical Indian Ocean. Part I: The role of remote forcing from the tropical Pacific. J. Climate, 20, 2917 2936

— and _ 2007b: Mechanisms for the interannual variability in the tropical Indian Ocean. Part II: Regional processes. J. Climate, 20, 2937-2960.

Joseph, P. V., 1990: Monsoon variability in relation to equatorial trough activity over India and west Pacific Oceans. Mausam, 41, 291-296.

_, J. K. Eischeid, and R. J. Pyle, 1994: Interannual variability of the onset of the Indian summer monsoon and its association with atmospheric features, El Niño and sea surface temperature anomalies. J. Climate, 7, 81-105.

Kalnay, E., and Coauthors, 1996: The NCEP/NCAR 40-Year Reanalysis Project. Bull. Amer. Meteor. Soc., 77, 437-471.

Kistler, R., and Coauthors, 2001: The NCEP-NCAR 50-Year Reanalysis: Monthly means CD-ROM and documentation. Bull. Amer. Meteor. Soc., 82, 247-267.

Kitoh, A., 2007: Variability of Indian monsoon-ENSO relationship in a 1000-year MRI-CGCM2.2 simulation. Nat. Hazards, 42, 261-272.

Krishna Kumar, K., B. Rajagopalan, and M. Cane, 1999: On the 
weakening relationship between the Indian monsoon and ENSO. Science, 284, 2156-2159.

,,-- M. Hoerling, G. Bates, and M. Cane, 2006: Unraveling the mystery of Indian monsoon failure during El Niño. Science, 314, 115-119.

Lawrence, D. M., and P. J. Webster, 2001: Interannual variations of the intraseasonal oscillation in the South Asian summer monsoon region. J. Climate, 14, 2910-2922.

Lee, T., 2004: Decadal weakening of the shallow overturning circulation in the south Indian Ocean. Geophys. Res. Lett., 31, L18305, doi:10.1029/2004GL020884.

Lévy, M., D. Shankar, J.-M. André, S. S. C. Shenoi, F. Durand, and C. de Boyer Montégut, 2007: Basin-wide seasonal evolution of the Indian Ocean's phytoplankton blooms. J. Geophys. Res., 112, C12014, doi:10.1029/2007JC004090.

Li, T., C.-W. Tham, and C.-P. Chang, 2001: A coupled air-seamonsoon oscillator for the tropospheric biennial oscillation. J. Climate, 14, 752-764.

Loschnigg, J., and P. J. Webster, 2000: A coupled oceanatmosphere system of SST modulation for the Indian Ocean. J. Climate, 13, 3342-3360.

—, G. A. Meehl, P. J. Webster, J. M. Arblaster, and G. P. Compo, 2003: The Asian monsoon, the tropospheric biennial oscillation and the Indian Ocean Dipole in the NCAR CSM. J. Climate, 16, 1617-1642.

Luo, J.-J., S. Masson, S. K. Behera, P. Delecluse, S. Gualdi, A. Navarra, and T. Yamagata, 2003: South Pacific origin of the decadal ENSO-like variation as simulated by a coupled GCM. Geophys. Res. Lett., 30, 2250, doi:10.1029/ 2003GL018649.

,,,--- S. Shingu, and T. Yamagata, 2005a: Seasonal climate predictability in a coupled OAGCM using a different approach for ensemble forecasts. J. Climate, 18, 4474-4497.

,-- E. Roeckner, G. Madec, and T. Yamagata, 2005b: Reducing climatology bias in an ocean-atmosphere CGCM with improved coupling physics. J. Climate, 18, 2344-2360.

,,--- , and T. Yamagata, 2007: Experimental forecasts of Indian Ocean Dipole using a coupled OAGCM. J. Climate, 20, 2178-2190.

,,--- , and — 2008: Extended ENSO predictions using a fully coupled ocean-atmosphere model. J. Climate, 21, 84-93.

Madden, R. A., and P. R. Julian, 1972: Description of global-scale circulation cells in the tropics with a 40-50 day period. $J$. Atmos. Sci., 29, 1109-1123.

Madec, G., P. Delecluse, M. Imbard, and C. Levy, 1998: OPA 8.1 ocean general circulation model reference manual. Notes du pôle de modélisation de l'IPSL 11, 91 pp. [Available online at http://www.lodyc.jussieu.fr/NEMO/general/manual/ Doc_OPA8.1.pdf.]

Masson, S., and Coauthors, 2005: Impact of barrier layer on winter-spring variability of the southeastern Arabian Sea. Geophys. Res. Lett., 32, L07703, doi:10.1029/2004GL021980.

Masumoto, Y., and G. Meyers, 1998: Forced Rossby waves in the southern tropical Indian Ocean. J. Geophys. Res., 103, 27 589-27 602 .

Mathew, R., and Y. Tanimoto, 2007: Role of SST over the Indian Ocean in influencing the intraseasonal variability of the Indian summer monsoon. J. Meteor. Soc. Japan, 85, 349-358.

Matsuno, T., 1966: Quasi-geostrophic motions in the equatorial area. J. Meteor. Soc. Japan, 44, 25-43.

Meehl, G. A., and J. M. Arblaster, 2001: The tropospheric bien- nial oscillation and Indian monsoon rainfall. Geophys. Res. Lett., 28, 1731-1734.

_, and _ 2002a: The tropospheric biennial oscillation and Asian-Australian monsoon rainfall. J. Climate, 15, 722-744. , and $-2002 \mathrm{~b}$ : Indian monsoon GCM sensitivity experiments testing tropospheric biennial oscillation transition conditions. J. Climate, 15, 923-944.

$\longrightarrow$, - and J. Loschnigg, 2003: Coupled ocean-atmosphere dynamical processes in the tropical Indian and Pacific Ocean regions and the TBO. J. Climate, 16, 2138-2158.

—, C. Covey, B. McAvaney, M. Latif, and R. J. Stouffer, 2005: Overview of the Coupled Model Intercomparison Project. Bull. Amer. Meteor. Soc., 86, 89-93.

Mooley, D. A., and B. Parthasarathy, 1984: Fluctuations in allIndia summer monsoon rainfall during 1871-1978. Climatic Change, 6, 287-301.

, and D. A. Paolino Jr., 1988: A predictive monsoon signal in the surface level thermal field over India. Mon. Wea. Rev., 116, 339-352.

_ B. Parthasarathy, and G. B. Pant, 1986: Relationships between Indian summer monsoon rainfall and location of the ridge at the $500-\mathrm{mb}$ level along $75^{\circ} \mathrm{E}$. J. Climate Appl. Meteor., 25, 633-640.

Murtugudde, R., and A. J. Busalacchi, 1999: Interannual variability of the dynamics and thermodynamics of the tropical Indian Ocean. J. Climate, 12, 2300-2326.

- J. P. McCreary, and A. J. Busalacchi, 2000: Oceanic processes associated with anomalous events in the Indian Ocean with relevance to 1997-1998. J. Geophys. Res., 105, 32953306.

- R. Seager, and P. Thoppil, 2008: Arabian Sea response to monsoon variations. Paleooceanography, 22, PA4217, doi:10.1029/2007PA001467.

Ninomiya, K., and C. Kobayashi, 1999: Precipitation and moisture balance of the Asian summer monsoon in 1991 Part II: Moisture transport and moisture balance. J. Meteor. Soc. Japan, 77, 77-99.

Nitta, T., and S. Yamada, 1989: Recent warming of tropical sea surface temperature and its relationship to the Northern Hemisphere circulation. J. Meteor. Soc. Japan, 67, 375-383.

Ogasawara, N., A. Kitoh, T. Yasunari, and A. Noda, 1999: Tropospheric biennial oscillation of the ENSO-monsoon system in the MRI coupled GCM. J. Meteor. Soc. Japan, 77, 12471270.

Pant, G. B., and K. Rupa Kumar, 1997: Climates of South Asia. J. Wiley and Sons, $320 \mathrm{pp}$.

Parthasarathy, B., H. F. Diaz, and J. K. Eischeid, 1988: Prediction of all-India summer monsoon rainfall with regional and largescale parameters. J. Geophys. Res., 93, 5341-5350.

— K. Rupa Kumar, and V. R. Deshpande, 1991a: Indian summer monsoon rainfall and $200 \mathrm{mb}$ meridional wind index: Application for long-range prediction. Int. J. Climatol., 11, $165-176$

, -, and A. A. Munot, 1991b: Evidence of secular variations in Indian monsoon rainfall-circulation relationships. $J$. Climate, 4, 927-938.

,$- \ldots$, and -1992 : Surface pressure and summer monsoon rainfall over India. Adv. Atmos. Sci., 9, 359-366.

Périgaud, C., and P. Delecluse, 1993: Interannual sea level variations in the tropical Indian Ocean from Geosat and shallow water simulations. J. Phys. Oceanogr., 23, 1916-1934.

Rao, K. G., and B. N. Goswami, 1988: Interannual variations of 
sea surface temperature over the Arabian Sea and the Indian monsoon: A new perspective. Mon. Wea. Rev., 116, 558-568.

- , and S. K. Behera, 2005: Subsurface influence on SST in the tropical Indian Ocean: Structure and interannual variability. Dyn. Atmos. Oceans, 39, 103-135.

Reverdin, G., 1987: The upper equatorial Indian Ocean: The climatological seasonal cycle. J. Phys. Oceanogr., 17, 903-927. , D. Cadet, and D. Gutzler, 1986: Interannual displacements of convection and surface circulation over the equatorial Indian Ocean. Quart. J. Roy. Meteor. Soc., 112, 43-46.

Reynolds, R. W., N. A. Rayner, T. M. Smith, D. C. Stokes, and W. Wang, 2002: An improved in situ and satellite SST analysis for climate. J. Climate, 15, 1609-1625.

Roeckner, E., and Coauthors, 1996: The atmospheric general circulation model ECHAM-4: Model description and simulation of present-day climate. Max-Planck-Institut für Meteorologie Rep. 218, 90 pp.

Saji, N. H., B. N. Goswami, P. N. Vinayachandran, and T. Yamagata, 1999: A dipole mode in the tropical Indian Ocean. $\mathrm{Na}$ ture, 401, 360-363.

Schoenefeldt, R., and F. A. Schott, 2006: Decadal variability of the Indian Ocean cross-equatorial exchange in SODA. Geophys. Res. Lett., 33, L08602, doi:10.1029/2006GL025891.

Schott, F. A., and J. P. McCreary Jr., 2001: The monsoon circulation of the Indian Ocean. Prog. Oceanogr., 51, 1-123.

—, M. Dengler, and R. Schoenefeldt, 2002: The shallow overturning circulation of the Indian Ocean. Prog. Oceanogr., 53, 57-103.

—, S.-P. Xie, and J. P. McCreary Jr., 2008: Indian Ocean circulation and climate variability. Rev. Geophys., in press.

Shukla, J., 1975: Effect of Arabian sea-surface temperature anomaly on Indian summer monsoon: A numerical experiment with the GFDL model. J. Atmos. Sci., 32, 503-511.

_ 1987: Interannual variability of monsoons. Monsoons, J. S. Fein and P. L. Stephens, Eds., J. Wiley and Sons, 339-463.

Slingo, J., H. Spencer, B. Hoskins, P. Berrisford, and E. Black, 2004: The meteorology of the western Indian Ocean and the influence of the east African highlands. Philos. Trans. Roy. Soc. London, A363, 25-42.

Smith, T. M., and R. W. Reynolds, 2004: Improved extended reconstruction of SST, 1854-1997. J. Climate, 17, 2466-2477.

Terray, P., 1995: Space-time structure of monsoon interannual variability. J. Climate, 8, 2595-2619.

ture and El Niño-Southern Oscillation: A new perspective. $J$. Climate, 18, 1351-1368.

- F. Chauvin, and H. Douville, 2007: Impact of southeast Indian Ocean sea surface temperature anomalies on monsoon-ENSO-dipole variability in a coupled ocean-atmosphere model. Climate Dyn., 28, 553-580.

Valcke, S., L. Terray, and A. Piacentini, 2000: The OASIS coupler user guide version 2.4. CERFACE Tech. Rep. TR/CGMC/ 00-10, 85 pp.

Vecchi, G. A., and D. E. Harrison, 2004: Interannual Indian rainfall variability and Indian Ocean sea surface temperature anomalies. Earth's Climate: The Ocean-Atmosphere Interac- tion, Geophys. Monogr., Vol. 147, Amer. Geophys. Union, 247-259.

Vialard, J., and Coauthors, 2008: Cirene: Air-sea interactions in the Seychelles-Chagos thermocline ridge region. Bull. Amer. Meteor. Soc., in press.

Walker, G. T., 1924: Correlations in seasonal variations of weather, IX. A further study of world weather, World Weather II. Mem. India Meteor. Dep., 24, 275-332.

Washington, W. M., R. M. Chervin, and G. V. Rao, 1977: Effects of a variety of Indian Ocean surface temperature anomaly patterns on the summer monsoon circulation: Experiments with the NCAR general circulation model. Pure Appl. Geophys., 115, 1335-1356.

Webster, P. J., V. Magaña, T. Palmer, J. Shukla, R. Tomas, M. Yanai, and T. Yasunari, 1998: Monsoon: Processes, predictability, and the prospects for prediction. J. Geophys. Res., 103, 14 451-14 510.

A. M. Moore, J. P. Loschnigg, and R. R. Leben, 1999: Coupled ocean-atmosphere dynamics in the Indian Ocean during 1997-98. Nature, 401, 356-360.

Wiggert, J. D., R. G. Murtugudde, and C. R. McClain, 2002: Processes controlling interannual variations in wintertime, northeast monsoon: Primary productivity in the central Arabian Sea. Deep-Sea Res. II, 49, 2319-2343.

$\mathrm{Wu}$, R. and B. P. Kirtman, 2005: Roles of Indian and Pacific Ocean air-sea coupling in tropical atmospheric variability. Climate Dyn., 25, 155-170.

Xie, P., and P. A. Arkin, 1996: Analyses of global monthly precipitation using gauge observations, satellite estimates and numerical model predictions. J. Climate, 9, 840-858.

Xie, S.-P., H. Annamalai, F. Schott, and J. P. McCreary Jr., 2002: Origin and predictability of south Indian Ocean climate variability. J. Climate, 15, 864-874.

, H. Xu, N. H. Saji, Y. Wang, and W. T. Liu, 2006: Role of narrow mountains in large-scale organization of Asian monsoon convection. J. Climate, 19, 3420-3429.

Yamagata, T., S. K. Behera, J.-J. Luo, S. Masson, M. R. Jury, and S. A. Rao, 2004: Coupled ocean-atmosphere variability in the tropical Indian Ocean. Earth's Climate: The OceanAtmosphere Interaction, Geophys. Monogr., Vol. 147, Amer. Geophys. Union, 189-212.

Yang, J., Q. Liu, S.-P. Xie, Z. Liu, and L. Wu, 2007: Impact of the Indian Ocean SST basin mode on the Asian summer monson. Geophys. Res. Lett., 34, L02708, doi:10.1029/2006GL028571.

Yasunari, T., 1979: Cloudiness fluctuations associated with the northern hemisphere summer monsoon. J. Meteor. Soc. Japan, 57, 227-242.

Yokoi, T., T. Tozuka, and T. Yamagata, 2008: Seasonal variation of the Seychelles dome. J. Climate, 21, 3740-3754.

Yu, J.-Y., and K. M. Lau, 2005: Contrasting Indian Ocean SST variability with and without ENSO influence: A coupled atmosphere-ocean GCM study. Meteor. Atmos. Phys., 90, 179191.

- S. P. Weng, and J. D. Farrara, 2003: Ocean roles in the TBO transitions of the Indian-Australian monsoon system. J. Climate, 16, 3072-3080. 